\title{
Aerosol particle number size distributions and particulate light absorption at the ZOTTO tall tower (Siberia), 2006-2009
}

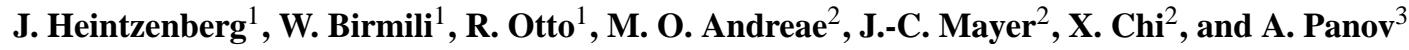 \\ ${ }^{1}$ Leibniz-Institute for Tropospheric Research, Permoserstrasse 15, 04318 Leipzig, Germany \\ ${ }^{2}$ Max-Planck-Institute for Chemistry, P.O. Box 3020, 55020 Mainz, Germany \\ ${ }^{3} \mathrm{VN}$ Sukachev Institute of Forest, Siberian Branch of the Russian Academy of Science, Akademgorodok, P.O. Box 26695, \\ 660036 Krasnoyarsk, Russia
}

Received: 17 December 2010 - Published in Atmos. Chem. Phys. Discuss.: 17 January 2011

Revised: 17 August 2011 - Accepted: 18 August 2011 - Published: 25 August 2011

\begin{abstract}
This paper analyses aerosol particle number size distributions, particulate absorption at $570 \mathrm{~nm}$ wavelength and carbon monoxide (CO) measured between September 2006 and January 2010 at heights of 50 and $300 \mathrm{~m}$ at the Zotino Tall Tower Facility (ZOTTO) in Siberia $\left(60.8^{\circ} \mathrm{N}\right.$; $89.35^{\circ} \mathrm{E}$ ). Average number, surface and volume concentrations are broadly comparable to former studies covering shorter observation periods. Fits of multiple lognormal distributions yielded three maxima in probability distribution of geometric mean diameters in the Aitken and accumulation size range and a possible secondary maximum in the nucleation size range below $25 \mathrm{~nm}$. The seasonal cycle of particulate absorption shows maximum concentrations in high winter (December) and minimum concentrations in mid-summer (July). The 90th percentile, however, indicates a secondary maximum in July/August that is likely related to forest fires. The strongly combustion derived $\mathrm{CO}$ shows a single winter maximum and a late summer minimum, albeit with a considerably smaller seasonal swing than the particle data due to its longer atmospheric lifetime. Total volume and even more so total number show a more complex seasonal variation with maxima in winter, spring, and summer. A cluster analysis of back trajectories and vertical profiles of the pseudo-potential temperature yielded ten clusters with three levels of particle number concentration: Low concentrations in Arctic air masses $\left(400-500 \mathrm{~cm}^{-3}\right)$, mid-level concentrations for zonally advected air masses from westerly directions between $55^{\circ}$ and $65^{\circ} \mathrm{N}\left(600-800 \mathrm{~cm}^{-3}\right)$, and high concentrations for air masses advected from the belt of industrial and population centers in Siberia and Kazakhstan $\left(1200 \mathrm{~cm}^{-3}\right)$. The ob-
\end{abstract}

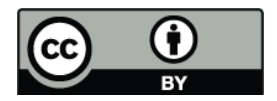

Correspondence to: J. Heintzenberg (jost@ tropos.de) servational data is representative for large parts of the troposphere over Siberia and might be particularly useful for the validation of global aerosol transport models.

\section{Introduction}

The Siberian landmass hosts an ecosystem that is globally relevant for the atmospheric budget of carbonaceous greenhouse gases, such as $\mathrm{CO}_{2}$ and $\mathrm{CH}_{4}$ (Schulze et al., 1999; Lloyd et al., 2002), but also aerosol particles. The aerosol's relevance derives from its ability to scatter and absorb incident light and lead to cloud activation, which influence the terrestrial radiation budget (Haywood and Boucher, 2000). Overall, the secondary aerosol over boreal forests is predicted to exert a net cooling effect on global climate (Spracklen et al., 2008). A particular concern, however, is how the vast Siberian ecosystem might change during the ongoing global warming, and which global consequences this will have (IGBP, 2007).

In contrast to its global relevance, Siberia is still poorly represented in atmospheric observation systems. Many previous atmospheric aerosol studies for Siberia have relied on satellite data (e.g., Cahoon et al., 1994; Stocks et al., 1998). In-situ physical, chemical and optical properties of aerosol particles have only been scarcely available.

Systematic in-situ observations of atmospheric aerosols in Siberia started in the late 1980s. The first observations included, for example, particle number size distributions and light scattering coefficients at Lake Baikal and Novosibirsk (Koutsenogii and Jaenicke, 1994; Koutsenogii, 1997, and references therein). During the summer months, these authors found total particle number concentrations between 2000 and $20000 \mathrm{~cm}^{-3}$ as well as modal geometric mean diameters

Published by Copernicus Publications on behalf of the European Geosciences Union. 
around 12,85 and $800 \mathrm{~nm}$. Due to the use of diffusion screens and impactors, the size resolution of these measurements was limited.

Vartiainen et al. (2007) reported particle and ion number concentrations measured along the Trans-Siberian railway using mobility spectrometers. During their 14-day campaign they encountered remote baseline concentrations around $500 \mathrm{~cm}^{-3}$ as well as peak values around $40000 \mathrm{~cm}^{-3}$ near anthropogenic sources. The duration of that experiment was, however, limited. In addition, the location of instruments on a running train required great care in identifying those sections of the data that were representative for remote, undisturbed conditions.

Using diffusion aerosol spectrometers, Dal Maso et al. (2008) analysed ambient particle number size distributions for one year in 2005/2006 at observation sites in Tomsk and Listvyanka, near Lake Baikal. The size range of the two instruments covered $3-250 \mathrm{~nm}$ and $3-50 \mathrm{~nm}$ at the two stations, respectively. The mean total particle number concentration at Tomsk, a station characterized as "rural" by the investigators, was around $2500 \mathrm{~cm}^{-3}$. At both sites, between 20 and 30 secondary particle formation events were observed during one year, which mainly occurred between March and June in Tomsk, but throughout January to August at Listvyanka. The average number of new particles formed per event amounted to $5700 \mathrm{~cm}^{-3}$ in Tomsk, and to $3340 \mathrm{~cm}^{-3}$ in Listvyanka.

Paris et al. (2009) conducted comprehensive aircraft observations of aerosol particles in the Siberian troposphere with a focus on ultrafine and fine particle number concentrations. Free tropospheric particle number concentrations varied between 60 and $460 \mathrm{~cm}^{-3}$, and were considerably inferior to those in the boundary layer $\left(100-7000 \mathrm{~cm}^{-3}\right)$. New ultrafine particles were concluded to be formed within the clean Siberian atmosphere, both in the boundary layer and in the free troposphere. While Paris et al. (2009) provided one of the most comprehensive atmospheric aerosol studies in Siberia, a limitation of their study remains the lack of particle size resolution.

The body of literature suggests that there is still considerable uncertainty about the spatio-temporal concentrations of particle mass and number, as well as their governing sources in the Siberian troposphere. Some presumed natural aerosol sources over Siberia include forest fires and secondary particle formation from the gas phase. Smoke released by Siberian forest fires could, for instance, be tracked down many thousand kilometers downwind within the entire Northern hemisphere (e.g., Cahoon et al., 1994; Stocks et al., 1998; Damoah et al., 2004; Müller et al., 2005).

Boreal forests have also been shown to represent a largescale source of secondary aerosol particle number and mass (e.g., Dal Maso et al., 2005, 2007; Pryor et al., 2008), with newly formed particle mass apparently being mainly organic compounds of biogenic origin (Tunved et al., 2006). One can think of additional natural aerosol sources that are relevant over Siberia, mainly affecting the coarse particle mode: pollen, vegetation debris, and wind-blown dust - mainly during dry summer periods, and sea spray - in the vicinity of the Arctic ocean during the ice-free period.

To reduce the large Siberian gap in surface-based atmospheric observations, the $300 \mathrm{~m}$ tall meteorological tower facility ZOTTO was erected 2006 near Zotino, Russia, in the heart of the Siberian ecosystem. Within the range of a few hundred kilometers around ZOTTO, anthropogenic sources are relatively scarce and far from each other. Thus, aerosol sampled at ZOTTO can be representative for a large area of the Siberian ecosystem. A study of the representativeness of the ZOTTO facility and first analyses of the particle size distribution data can be found in Heintzenberg et al. (2008) and Heintzenberg and Birmili (2010). The present report covers a statistical analysis of aerosol data taken through the first four years of operation of the ZOTTO facility (9/2006-1/2010). Beyond the particle size distribution, measurements of particulate absorption and $\mathrm{CO}$ as a tracer gas are discussed. With a cluster analysis of back trajectories, seasonally dependent major air mass pathways and the related aerosol size distributions are determined.

\section{Instrumental}

\subsection{The Zotino Tall Tower Facility (ZOTTO)}

Since 2006, a unique research platform is available in Central Siberia as the Zotino Tall Tower Facility (ZOTTO) at $60.8^{\circ} \mathrm{N} ; 89.35^{\circ} \mathrm{E}$, about $20 \mathrm{~km}$ west of the Yenisei river. The site lies in a vast region of forests and bogs, still relatively undisturbed by anthropogenic influences and relatively inhospitable because of its continental climate. The population density is low, but a moderate human impact on vegetation, e.g., by logging activities, is already visible. The climate is dominated by a large seasonal temperature cycle spanning from minima below $-55^{\circ} \mathrm{C}$ in winter to maxima above $+30{ }^{\circ} \mathrm{C}$ in summer. The tower is $300 \mathrm{~m}$ high and was designed for long-term atmospheric observations in Siberia that are representative for a very large spatial area. A significant benefit of tall tower sampling is also that measurements at greater heights are less prone to contamination by unavoidable local sources such as the diesel power generator of the facility.

Trace gas measurements obtained by aircraft in summer in the Zotino area (Lloyd et al., 2002) indicated a well-mixed planetary boundary layer by the depletion of carbon dioxide concentration as a result of daytime photosynthesis. This measurement shows that a $300 \mathrm{~m}$ sampling point on the tower should be largely representative for boundary layer air (indicated by an excess in biogenic oxygen isotopes), thus avoiding effects that are related to particle sources or sinks the shallow surface layer.

The tower and the adjacent underground laboratory were constructed between 2004 and 2006 by the Max Planck 
Society (http://www.bgc-jena.mpg.de/bgc-systems/projects/ zotto/index.shtml). The scientific leaders of the ZOTTO facility are the Max Planck Institute for Biogeochemistry in Jena, Germany, and the VN Sukachev Institute of Forest, Krasnoyarsk, Russia, together with the Max Planck Institute for Chemistry, Mainz, Germany. The VN Sukachev Institute of Forest continually operates and maintains the ZOTTO facility. More details on the motivation of ZOTTO and details on the infrastructure are given in Kozlova et al. $(2008,2009)$ and Winderlich et al. (2010).

\subsection{The aerosol inlet at ZOTTO}

Ambient aerosols at ZOTTO are collected through two inlet pipes, one reaching to the top of the tower at $300 \mathrm{~m}$ above ground, the other one to $50 \mathrm{~m}$ height. A computercontrolled valve system switches the aerosol sampling between the two levels every six minutes while maintaining the nominal $401 \mathrm{~min}^{-1}$ flow in both inlets. The details of the experimental set-up including a calibration of the inlet for particle losses are described in a specialized paper (Birmili et al., 2007) and in Heintzenberg et al. (2008).

Particles between 0.05 and $1 \mu \mathrm{m}$ in mobility diameter $\left(D_{p}\right)$ are nearly perfectly transmitted through the pipe. $10 \mathrm{~nm}$ particles are still transmitted at a reproducible efficiency of $20 \%$ (Birmili et al., 2007). The latter inlet calibration was used to correct all particle number size distributions in this paper. At the upper particle size end, gravitational settling is relevant in the final $10 \mathrm{~m}$ of horizontal pipe section. Gravitational losses were not calibrated experimentally, but estimated for horizontal laminar pipe flow after Brockmann (2001). Our estimation yielded a $50 \%$ particle transmission for particles around $3 \mu \mathrm{m}$ (aerodynamic Diameter $D_{\mathrm{ae}}$ ), which can be regarded as the upper size cut of the inlet. This size cut is irrelevant for the particle number size distribution measurements, but essential to the integrating optical aerosol measurements.

\subsection{Particle size distribution measurements}

Particle number size distributions in the diameter range 15$835 \mathrm{~nm}$ have been recorded continuously at ZOTTO since 9/2006 by a Differential Mobility Particle Sizer (DMPS). The instrument has been optimized for the special requirements of long-term operation at ZOTTO: automatic and largely unattended operation, low level of maintenance, long-term stability, avoidance of radioactive sources as a charging device due to legal restrictions.

Specifically, the DMPS uses a Hauke-type differential mobility analyzer (DMA; Winklmayr et al., 1991) with a center rod length of $28 \mathrm{~cm}$. Positive voltages up to $12500 \mathrm{~V}$ are applied, thus selecting negatively charged particles in the DMA. Particles downstream of the DMA are counted with a laminar flow condensation particle counter (CPC model 3762, TSI Inc., St Paul, USA). The sample flow through the particle counter was limited by a critical orifice to
$0.8 \pm 0.11 \mathrm{~min}^{-1}$. Single particles in the CPC are counted by digital data acquisition to provide an accurate concentration measure even in the case of very low particle concentrations.

A sheath flow of $51 \mathrm{~min}^{-1}$ is circulated in a closed loop, regulated by a computer-controlled air blower with adjustable rotational frequency. Changes of relative humidity $(\mathrm{RH})$ in the sheath air loop are damped by a silica gel adsorption dryer. Due to the relative dryness of ambient air sampled in Central Siberia, we observed no critical accumulation of moisture in the sheath air loop. In fact, RH stayed below $30 \%$ in all seasons.

As legal restrictions prevented the deployment of a radioactive source as an aerosol neutralizer, ambient aerosol particles are generally neutralized in a corona-discharge based aerosol neutralizer (Stommel and Riebel, 2004). This aerosol neutralizer consists of an aerosol chamber with an AC electrical discharge and was shown to perform in an equivalent fashion to the more common $\mathrm{Kr}^{85}$ neutralizer in ambient aerosol measurements. The time resolution of the DMPS is about $6 \mathrm{~min}$. After each measurement, the instrument switches between the $300 \mathrm{~m}$ and $50 \mathrm{~m}$ height levels to provide size distributions as a function of height.

After the multiple charge inversion and the particle loss corrections for the $300 \mathrm{~m}$ and $50 \mathrm{~m}$ inlet pipes (Birmili et al., 2007), the resulting particle size distributions are evaluated in 18 logarithmically equal size bins between 15 and $835 \mathrm{~nm}$. This particle size range roughly encompasses the accumulation mode $(100-835 \mathrm{~nm})$ - representative for aged atmospheric aerosols, the Aitken mode (50-100 nm) - representative for young aerosol particles only a few days old, and the nucleation mode $(<50 \mathrm{~nm})$ - representing the most recently formed aerosol particles. Additionally, particle mass concentrations were calculated from number size distributions assuming spherical particles and a gravimetric density of $1.6 \mathrm{~g} \mathrm{~cm}^{-3}$. The latter value is assumed to be representative for rural background aerosols.

Unfortunately, the aerosol neutralizer failed due to electrical problems during a lengthy period between February 2008 and April 2009, during which the DMPS was operated without neutralizer. Normally, the use of a charge neutralizer is mandatory in conjunction with a DMPS, since otherwise, the state of charging is poorly defined. However, it is known that aerosol particles reach the bipolar charge equilibrium after a sufficient residence time in the atmosphere. Gagné et al. (2008) examined the charging state of environmental particles over a boreal forest using a DMPS with and without a charge neutralizer. Their one-year observations suggest that deviations from the bipolar charge equilibrium play a role in the size range of the smallest particles $(<10 \mathrm{~nm})$ only. Apparently, nucleation mode particles readily reach the charge equilibrium after a residence time of only a few hours in an atmospheric setting comparable to ZOTTO with respect to latitude and the biogenic ecosystem.

As an additional check, we used instrumentation equivalent to that at ZOTTO in an urban air experiment in Leipzig 
(Germany). During three days we made alternating measurements with and without the use of a $\mathrm{Kr}^{85}$ neutralizer using a positive DMA voltage. The main result was that in their ambient state, urban ambient particles appeared to be undercharged, with relative efficiencies of $79 \%, 90 \%$, and $80 \%$ at the diameters 15,80 , and $800 \mathrm{~nm}$, respectively, compared to the bipolar charge equilibrium. Hence, we conclude that the concentrations observed by the ZOTTO DMPS during the period 2/2008-4/2009 might be too low by $20 \%$ at most. This estimate seems to be justified in view of the relatively large distance of the ZOTTO site to the emission sources of fresh anthropogenic aerosols.

\subsection{Particulate absorption measurements}

A single-wavelength Particle/Soot Absorption Photometer (PSAP, Radiance Research, Seattle, USA) was used in this study for measuring particulate light absorption. This method is based on the integrating plate technique, in which the change in optical transmission through a filter caused by particle deposition on the filter is related to the light absorption coefficient of the deposited particles. The raw or uncorrected absorption coefficient from the PSAP, $\sigma_{0}$, can be written as

$\sigma_{0}=\frac{\mathrm{A}}{V} \ln \left(\frac{\operatorname{Tr}_{t-\Delta t}}{\operatorname{Tr}_{t}}\right)$

where $\mathrm{A}$ is the area of the sample spot, $V$ is the volume of air drawn through area A during a given time period $\Delta t, \operatorname{Tr}_{t-\Delta t}$ and $\operatorname{Tr}_{t}$ are the filter transmissions before and after the time period.

However, it is known that this equation does not directly give the accurate aerosol absorption coefficient, because of the inherent errors caused by multiple scattering effects within the filter matrix and the light scattering by the collected particles (Bond et al., 1999; Virkkula et al., 2005). Several empirical methods have been suggested and modified for correcting these artifacts (Bond et al., 1999; Weingartner et al., 2003; Virkkula et al., 2005).

In this study we corrected our data for the scattering artifact as well as the calibration error after Virkkula et al. (2005). The particulate absorption coefficient was calculated from

$\sigma_{\mathrm{AP}}(\mathrm{PSAP})=\left(k_{0}+k_{1} \cdot\left(h_{0}+h_{1} \omega_{0}\right) \cdot \ln (\mathrm{Tr})\right) \cdot \sigma_{0}-s \cdot \sigma_{\mathrm{SP}}$

where $k_{0}, k_{1}, h_{0}, h_{1}$, and $\sigma$ are the constants listed in Table 3 in Virkkula et al. (2005) for a single-wavelength PSAP $(\lambda=574 \mathrm{~nm})$. Tr is the Transmission of the light through the filter, represents the scattering coefficients $(\lambda=574 \mathrm{~nm}), \omega$ is the single-scattering albedo calculated using the iterative procedure described in Virkkula's Eqs. (7)-(9) and Table 3.

It has been estimated that this type of empirical corrections limits the overall accuracy of PSAP measurements to ca. 20-30\% (Bond et al., 1999). Such estimates of the uncertainty in PSAP absorption are derived from laboratory measurements, typically made using non-absorbing (e.g., ammonium sulfate) or strongly absorbing (e.g., soot, nigrosin dye) particles, which are all solid when dry (Bond et al., 1999; Virkkula et al., 2005). Some later laboratory and field experiments suggested that the actual uncertainty in PSAP measurements in the field is likely to be significantly larger than 20-30\% (Cappa et al., 2008; Lack et al., 2008). The minimum detection limit (MDL) of the PSAP was estimated to be $0.025 \mathrm{Mm}^{-1}$ for our hourly-average data, based on two times the standard deviation of 1-min noise (with $60 \mathrm{~s}$ cycle time) reported in Virkkula et al. (2005) and adjusting for our longer averaging time.

At the site, the PSAP was attended regularly, and the filter was changed when the transmission had decreased to 0.7. The aerosol flow through the instrument varied slightly around a value of $0.31 \mathrm{~min}^{-1}$. The exact flow rate (average of at least three measurements) was measured every time the filter was changed, and was used for the sampling volume calculation. The measured diameter of the sampling spot on several filters was $5.2 \mathrm{~mm}$, which differs from the value of $5.0 \mathrm{~mm}$ given in the PSAP manual. In synchrony with the valve switching between the $300 \mathrm{~m}$ and $50 \mathrm{~m}$ height levels every six minutes, the filter transmission (Tr) from PSAP is recorded in the beginning and at the end of each individual sampling period (either for $300 \mathrm{~m}$ and $50 \mathrm{~m}$ height levels).

Our initial intention was to calculate the absorption coefficient during each of these time periods using the equations mentioned above, and then to derive separate 1-h averages for the two heights. However, it was found that this approach caused unacceptable noise due to instrumental instabilities related to humidity and pressure fluctuations when switching both sampling lines. To eliminate this effect, we first calculated the hourly absorption coefficient for air mixed from both sampling levels, using the transmission at the beginning and end of the hour and the total air volume that has passed the filter during this time. We then estimated the absorption values at $50 \mathrm{~m}$ and $300 \mathrm{~m}$ height levels, based on the scattering coefficients for the two height levels, which were measured independently by an integrating nephelometer (assuming for the two height levels being identical within one hour). The particulate scattering in air sampled from 50 and $300 \mathrm{~m}$ was measured using a TSI three-wavelength nephelometer (Model 3653 TSI, St. Paul, MN, USA) that measures at wavelengths of 450,550 , and $700 \mathrm{~nm}$. The scattering coefficients were corrected for illumination non-idealities according to Anderson and Ogren (2006) and interpolated to $574 \mathrm{~nm}$ using the nephelometer-derived scattering Ångström exponent Virkkula et al. (2005).

\subsection{Carbon monoxide measurements}

The carbon monoxide (CO) mixing ratios in air sampled from 50 and $300 \mathrm{~m}$ were measured by UV resonance 


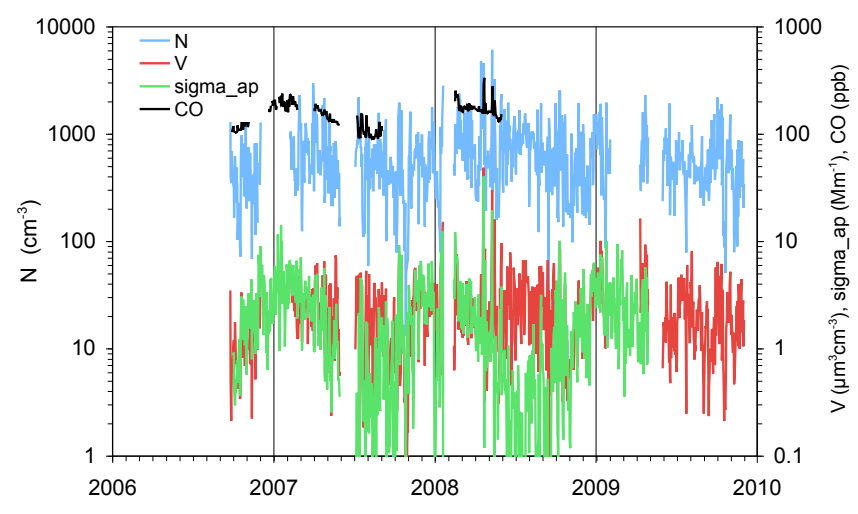

Fig. 1. Daily averages of total number $\left(N, \mathrm{~cm}^{-3}\right)$, total volume $\left(V, \mu \mathrm{m}^{3} \mathrm{~cm}^{-3}\right)$, particulate absorption at $570 \mathrm{~nm}$ wavelength $\left(\sigma_{\mathrm{ap}}\right.$, $\mathrm{M} \mathrm{m}^{-1}$ (average of the $50 \mathrm{~m}$ and $300 \mathrm{~m}$ ) levels), and carbon monoxide $(\mathrm{CO}, \mathrm{ppb})$ at $300 \mathrm{~m}$ at ZOTTO, Siberia.

fluorescence, using a Fast-CO-Monitor (Model AL 5002, Aerolaser $\mathrm{GmbH}$, Germany). Prior to measurement, the air was dried using a Nafion drier. Automated periodic zero and span calibrations were made to account for instrumental drift. The instrument was calibrated using a CO standard gas purchased from Scott-Marrin Inc. (Riverside, Cal., USA). The CO mixing ratio in this cylinder was determined to be $187.4 \mathrm{ppb}$ at the Max Planck Institute for Biogeochemistry (Jena, Germany) by calibration against standards from the WMO Central Calibration Laboratory (CCL; at NOAA/ESRL/GMD) (Kozlova et al., 2009). The original $\mathrm{CO}$ data, measured with a frequency of $3 \mathrm{~s}$, was converted to hourly averages to minimize uncertainties inherent in the data analysis methodology.

Quality control of the continuous CO data was accomplished by a bivariate regression analysis against independently measured data from flask samples, analyzed at the Max Planck Institute for Biogeochemistry. The regression analysis revealed a very good agreement of the two independent data sets, with an intercept of $5.1 \pm 4.2$ and a slope of $0.97 \pm 0.03$ ( \pm 1 standard error). A negligibly small offset is therefore obtained at ambient concentrations around typically observed values of 80-200 ppb.

\section{Results}

\subsection{Aerosol statistics}

The present data set covers the time period from September 2006 to January 2010 with several interruptions due to technical reasons and logistic constraints as indicated by the time series of daily averages of all parameters in Fig. 1.

\subsubsection{Integral aerosol parameters}

Statistics of total number, surface and volume concentrations (diameter range 15-835 nm) for 9/2006-1/2010 are collected in Table 1, both as annual averages and for the months MayAugust and the months November-February. The median particle number concentration including a quartile range was $570(330-940) \mathrm{cm}^{-3}$, the corresponding particle volume concentration being $1.9(1.0-3.3) \mu \mathrm{m}^{3} \mathrm{~cm}^{-3}$. Assuming a particle density of $1.6 \mathrm{~g} \mathrm{~cm}^{-3}$ the latter median would roughly correspond to a $\mathrm{PM}_{1}$ (particles with aerodynamic diameter $<1 \mu \mathrm{m}$ ) mass concentration of $3 \mu \mathrm{g} \mathrm{m}^{-3}$.

At first glance, these particle number concentrations seem to be similar to the remote baseline concentrations $\left(500 \mathrm{~cm}^{-3}\right)$ encountered in 2005 during the transect of the Trans-Siberian Railroad (Vartiainen et al., 2007). On the other hand, they appear significantly lower than long-term averages over the Boreal Forest in northern Finland, considering air masses of continental character only $\left(899 \mathrm{~cm}^{-3}\right.$ at the station Varriö; $840 \mathrm{~cm}^{-3}$ at the station Pallas) (Tunved et al., 2005).

For all integral parameters and all seasons the concentrations are higher at $50 \mathrm{~m}$ than at $300 \mathrm{~m}$, with their ratio being highest in the number (ca. 1.3) and lowest in the volume concentrations (ca. 1.1). This suggests the presence of particle number sources near the ground. It turned out difficult to judge which particle sources could be responsible for this vertical gradient.

Local particle sources, which include the diesel power generator of the station and the sporadic truck traffic to the village of Zotino are unlikely to cause this discrepancy. A reason is that the signature particle size distributions that are typical for diesel engine emissions (a soot particle mode combined with a nucleation mode) were encountered in substantial number neither at the $300 \mathrm{~m}$ nor at the $50 \mathrm{~m}$ level. Although we do not have the experimental means to prove this, a prime possibility seems to be a particle flux from the boreal forest surrounding the station.

Particle number and volume concentrations also exhibit a seasonal cycle (Fig. 2). At both heights, median number and surface concentrations are higher by 10 to $20 \%$ in summer compared to winter, whereas volume concentrations are $10 \%$ lower at $50 \mathrm{~m}$ in summer than in winter. At $300 \mathrm{~m}$ only the cleanest $25 \%$ of volume concentrations are $10 \%$ lower in summer than in winter. The summer/winter differences in Table 1 suggest a closer look at the seasonal variation of the integral aerosol parameters, which we present for $300 \mathrm{~m}$ height in terms of monthly percentiles for total number and volume concentrations in Fig. 2.

The particle number shows three maxima in winter, spring, and summer, whereas the total volume only exhibits a double maximum in winter and summer. A first hypothesis is that the winter maxima, centered around December, are due to northern hemispheric fossil fuel combustion. The June/July maximum coincides with the most probable period of forest 
Table 1. 25th, 50th, and 75th percentiles of number $(N)$, surface $(S)$, and volume $(V)$ concentrations at 50 and $300 \mathrm{~m}$ height at ZOTTO, Siberia. The statistics are given as total, for the summer months May-August, and for the winter months November-February. Ratios $50 \mathrm{~m} / 300 \mathrm{~m}$ and summer/winter are added.

\begin{tabular}{|c|c|c|c|c|c|c|c|c|c|c|c|c|}
\hline \multirow[b]{2}{*}{ Parameter } & \multirow[b]{2}{*}{$\%$} & \multicolumn{3}{|c|}{ Total } & \multicolumn{3}{|c|}{ May-August } & \multicolumn{3}{|c|}{ November-February } & \multirow{2}{*}{$\begin{array}{c}50 \mathrm{~m} \\
\text { Summer/ } \\
\text { winter }\end{array}$} & \multirow{2}{*}{$\begin{array}{c}300 \mathrm{~m} \\
\text { Summer/ } \\
\text { winter }\end{array}$} \\
\hline & & $50 \mathrm{~m}$ & $300 \mathrm{~m}$ & $\begin{array}{l}50 \mathrm{~m} / \\
300 \mathrm{~m}\end{array}$ & $50 \mathrm{~m}$ & $300 \mathrm{~m}$ & $\begin{array}{l}50 \mathrm{~m} / \\
300 \mathrm{~m}\end{array}$ & $50 \mathrm{~m}$ & $300 \mathrm{~m}$ & $\begin{array}{l}50 \mathrm{~m} / \\
300 \mathrm{~m}\end{array}$ & & \\
\hline \multirow{3}{*}{$\begin{array}{c}N \\
\mathrm{~cm}^{-3}\end{array}$} & 25 & 420 & 330 & 1.3 & 450 & 400 & 1.1 & 380 & 280 & 1.4 & 1.2 & 1.4 \\
\hline & 50 & 720 & 570 & 1.3 & 710 & 620 & 1.1 & 650 & 520 & 1.3 & 1.1 & 1.2 \\
\hline & 75 & 1160 & 940 & 1.2 & 1050 & 930 & 1.1 & 1150 & 920 & 1.3 & 0.9 & 1.0 \\
\hline \multirow{3}{*}{$\begin{array}{c}S \\
\mu \mathrm{m}^{2} \mathrm{~cm}^{-3}\end{array}$} & 25 & 29 & 25 & 1.2 & 34 & 30 & 1.2 & 30 & 26 & 1.1 & 1.2 & 1.1 \\
\hline & 50 & 52 & 44 & 1.2 & 55 & 51 & 1.1 & 50 & 43 & 1.2 & 1.1 & 1.2 \\
\hline & 75 & 84 & 73 & 1.2 & 86 & 78 & 1.1 & 87 & 74 & 1.2 & 1.0 & 1.1 \\
\hline \multirow{3}{*}{$\mu \mathrm{m}^{3} \mathrm{~cm}^{-3}$} & 25 & 1.2 & 1.0 & 1.2 & 1.3 & 1.1 & 1.2 & 1.5 & 1.2 & 1.2 & 0.9 & 0.9 \\
\hline & 50 & 2.1 & 1.9 & 1.1 & 2.2 & 2.0 & 1.1 & 2.4 & 2.1 & 1.1 & 0.9 & 1.0 \\
\hline & 75 & 3.7 & 3.3 & 1.1 & 3.8 & 3.4 & 1.1 & 4.3 & 3.6 & 1.2 & 0.9 & 1.0 \\
\hline
\end{tabular}

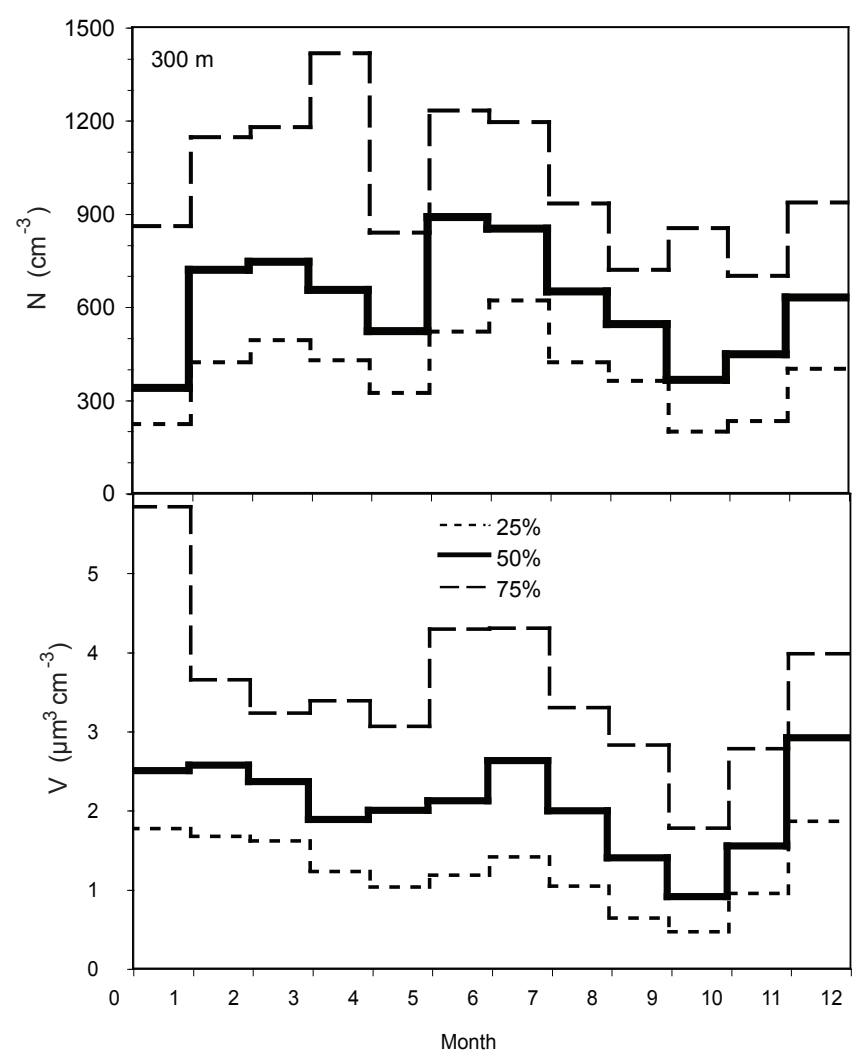

Fig. 2. Monthly percentiles of total number $\left(N, \mathrm{~cm}^{-3}\right)$, and total volume $\left(V, \mu \mathrm{m}^{3} \mathrm{~cm}^{-3}\right)$ in $300 \mathrm{~m}$ height at ZOTTO, Siberia for the period $9 / 2006-1 / 2010$.

fires in the region (Soja et al., 2004a,b; Achard et al., 2006; Vasileva et al., 2011). The February-April and June peaks in number concentration could generally point to the type of secondary new particle formation observed in all continental boundary layers (Kulmala et al., 2004).

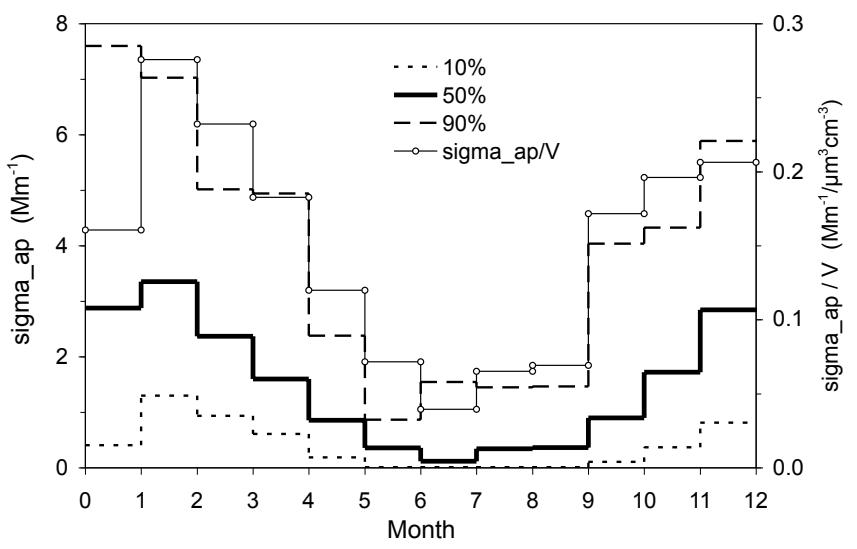

Fig. 3. Monthly percentiles $(10,50$, and $90 \%)$ of particulate absorption coefficients $\left(\sigma_{\text {ap }}\right.$ in $\mathrm{M} \mathrm{m}^{-1}$ ) at $570 \mathrm{~nm}$ wavelength in $300 \mathrm{~m}$ height at ZOTTO, Siberia taken over the time period for the period 9/2006-4/2009; averages of $50 \mathrm{~m}$ and $300 \mathrm{~m}$. The ratio of median $\sigma_{\text {ap }}$ to median volume concentration is depicted as thin line with circles.

Particulate absorption measured with the PSAP for the particle size range $<3 \mu \mathrm{m}$ is an integral aerosol parameter that is strongly connected to combustion sources. In Fig. 3 we present monthly percentiles of $\sigma_{\mathrm{ap}}$ for comparison with the annual course of the DMPS data. Particulate absorption shows a smooth seasonal variation with a high winter maximum and a broad summer minimum. The 10th percentile decreases to constant, low values during May through $\mathrm{Au}-$ gust whereas the 90th percentile indicates the occurrence of elevated concentrations in June-August, consistent with the forest fire emissions we speculated about above. As with particle number and volume, the monthly medians of particulate absorption are always lower at $300 \mathrm{~m}$ than at $50 \mathrm{~m}$ (not shown). 


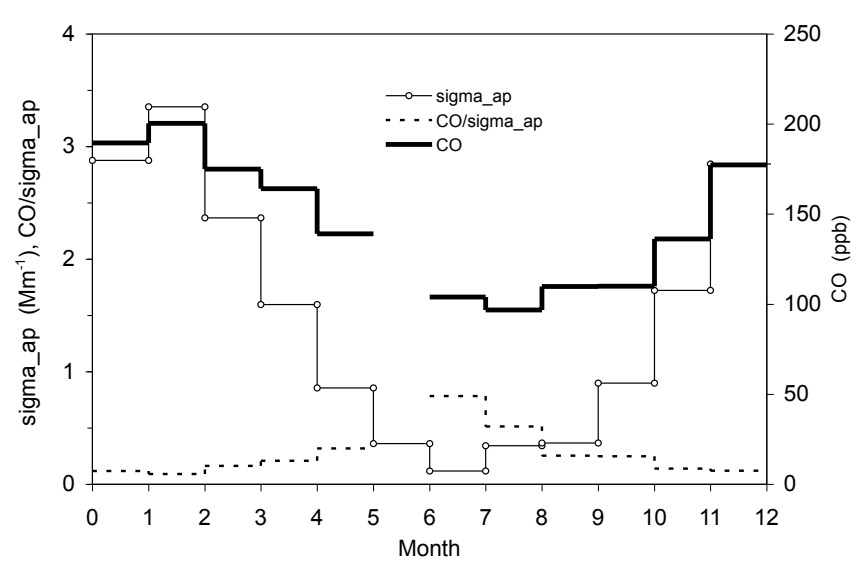

Fig. 4. Monthly medians of the particulate absorption coefficient at $570 \mathrm{~nm}\left(\sigma_{\mathrm{ap}}, \mathrm{Mm}^{-1}\right), \mathrm{CO}$ concentrations $(\mathrm{ppb})$, and the ratio $\mathrm{CO} / \sigma_{\text {ap }}$ at ZOTTO; averages of $50 \mathrm{~m}$ and $300 \mathrm{~m}$.

Kozlov et al. (2008) discovered that the mass fraction of black carbon in sub-micrometer aerosol can serve as an indicator of smoke from remote forest fires in Siberia. Their long-term study revealed that the black carbon fraction in forest fire smoke is lower than in the average background aerosol, i.e. this smoke is less absorbing. We consequently used the total particle volume concentration $V(<835 \mathrm{~nm})$ as a proxy for the sub-micrometer mass concentrations and plotted the ratio $\sigma_{\mathrm{ap}} / V$ in Fig. 3. This ratio neatly follows absolute particulate absorption coefficients with a minimum during June/July, i.e. when we suspected a maximum likelihood of regional forest fires.

Carbon monoxide (CO) measurements were only operational during three of the four years of the present report, and no CO data were available in any month of June. Nevertheless, $\mathrm{CO}$ exhibits a smooth seasonal variation in Fig. 4 with a maximum during the late winter when total volume and $\sigma_{\text {ap }}$ peaked and a broad minimum during the period spring through fall (lowest values in July). Like soot and other particulate matter, $\mathrm{CO}$ is a tracer for combustion processes, especially biomass burning. However, due to its longer lifetime in the atmosphere and the presence of a substantial global background concentration, the seasonal swing of $\mathrm{CO}$ is substantially smaller than that of $\sigma_{\text {ap }}$ leading to a clear summer maximum in the ratio $\mathrm{CO} / \sigma_{\text {ap }}$ in Fig. 4.

\subsubsection{Particle size distributions}

For a better statistical description of the number size distributions, each 18-channel particle size spectrum was reduced to nine parameters by fitting three lognormal functions (Heintzenberg, 1994) to any measured distribution, starting from hourly median data. The fitting algorithm programmed in FORTRAN utilized a random search of a given space of geometric standard deviations $\sigma_{g}$ of $1.1 \leq \sigma_{\mathrm{g}} \leq 2.3$ and geometric mean diameters $D_{\mathrm{g}}$ of $10 \leq D_{\mathrm{g}} \leq 1000 \mathrm{~nm}$ combined

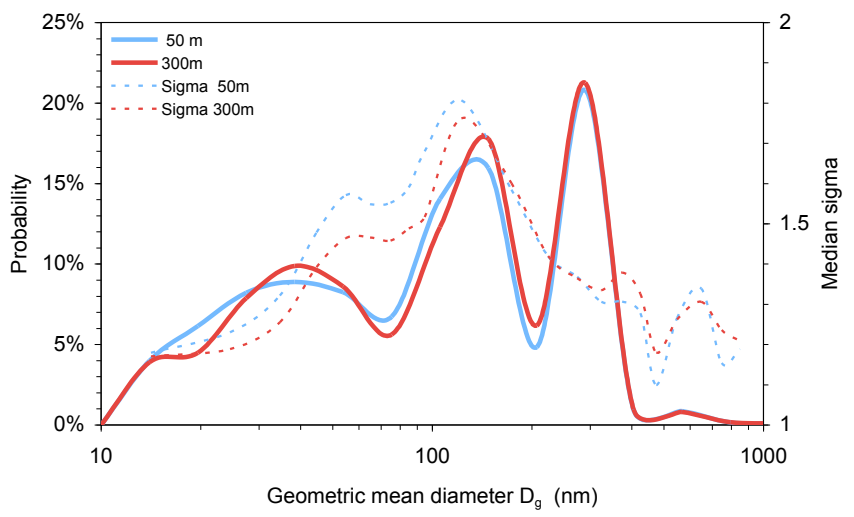

Fig. 5. Probability distribution of modal diameters of one-hourmedian number size distributions taken at $50 \mathrm{~m}$ and $300 \mathrm{~m}$ height at ZOTTO (full lines). The size distributions were fitted with a maximum of three lognormal modes in a range of $10-1000 \mathrm{~nm}$ modal diameters. The dashed lines give median values of geometric standard deviations as a function of geometric mean diameter.

with a least square fit of total number concentrations $N_{m}$ $(m=1,3)$ within each of the three modes. Within each fitting process the number of modes was minimized while maintaining the constraint of $20 \%$ relative deviation between measured and fitted data.

Probability distribution functions of $D_{\mathrm{g}}$ were constructed by normalizing the number of occurrences of a certain value of $D_{\mathrm{g}}$ to the total number of lognormally fitted size distributions. The resulting functions at both $50 \mathrm{~m}$ and $300 \mathrm{~m}$, and the size distribution of median $\sigma_{\mathrm{g}}$ at both elevations drawn in Fig. 5 clearly show that the shape of the size distributions is quite similar at both $50 \mathrm{~m}$ and $300 \mathrm{~m}$. Most frequent geometric mean diameters are found (with decreasing probability) at 300,150 , and $40 \mathrm{~nm}$. The broadest lognormal modes are found around $100 \mathrm{~nm}$ with geometric standard deviations $\sigma_{\mathrm{g}}$ decreasing towards both smaller and larger particle sizes.

Figure 6 compares percentiles of the fitted number size distributions at $300 \mathrm{~m}$ height in the four summer months May through August with the winter months November through February. The median size distributions for the smallest and the largest $5 \%$ of the total number concentrations are given for both seasons. The respective total particle numbers were 290 and $4100 \mathrm{~cm}^{-3}$ in summer, and 220 and $3400 \mathrm{~cm}^{-3}$ in winter. In summer more large-Aitken and/or small-accumulation mode particles occur, whereas in winter considerably more small-Aitken and large-accumulation mode particles are found in both extreme sub-populations. The prominent occurrence of a mode at about $100 \mathrm{~nm}$ in the size distribution of the largest concentration periods in summer (full red line in Fig. 6) is in line with contributions from biomass burning during this season, as this is the typical modal size of relatively fresh biomass smoke (Guyon et al., 2005; Reid et al., 2005). It is worth to note that the cleanest air masses in winter contain considerably more particulate 


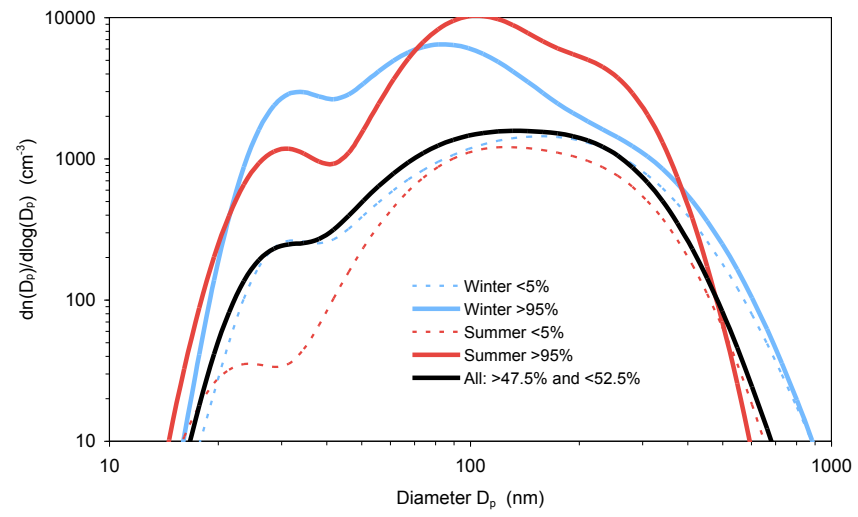

Fig. 6. Median number size distributions at $300 \mathrm{~m}$ height in air masses with the smallest ( $<5 \%$, dashed), and highest ( $>95 \%$, full lines) values of the total number concentration at ZOTTO in summer (May through August, red), and winter (November through February, blue). In black: Median number size distributions in all air masses with values between 47.5 and $52.5 \%$ of the total number concentration.

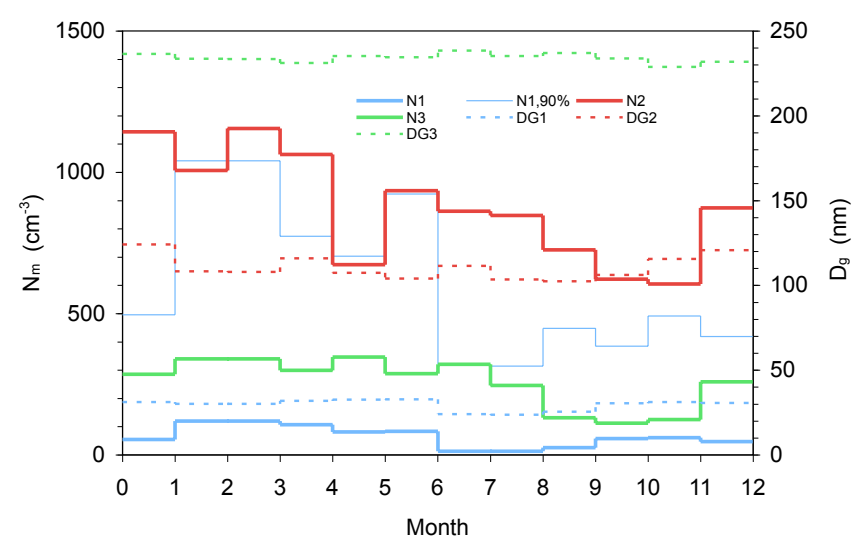

Fig. 7. Monthly medians of the total particle numbers $N_{\mathrm{m}}\left(N_{1}-N_{3}\right.$, $\mathrm{cm}^{-3}$, full lines) and geometric mean diameters $D_{\mathrm{g}}\left(D_{\mathrm{g} 1}-D_{\mathrm{g} 3}, \mathrm{~nm}\right.$, dashed lines) of three lognormal distributions fitted to the particle number size distributions measured at ZOTTO. The 90th percentile of $N_{1}$ is drawn as thin full line.

volume (i.e. particles $>100 \mathrm{~nm}$ ) than the cleanest air masses in summer.

Monthly medians of the modal concentrations, $N_{\mathrm{m}}$ and the geometric mean diameters $D_{\mathrm{g}}$ shed some more light on the seasonal aerosol variations than is visible from the integral parameters discussed in Sect. 3.1.2. In Fig. 7 the first (30$40 \mathrm{~nm}$ ), and second modes (100-130 nm) follow to some extent the annual course of the integral size distribution parameters, $N, S$, and $V$, as shown in Fig. 2. As expected from that figure the absolute seasonal variations of all three modes in both concentrations and size are not very large. Both mode 2 and mode 3 have a broad minimum in late summer and fall. Mode 3 has a wide maximum connecting winter and early summer whereas mode 2 has a clear late winter maximum, typical for Arctic haze.

The smallest particles, fitted by mode 1 , have their smallest monthly median concentrations in the summer months June through August when their geometric mean diameters also are smallest. Because of high concentrations of ultrafine particles $(<25 \mathrm{~nm})$ being rather rare at ZOTTO, we also display monthly 90th percentiles of $N_{1}$ in Fig. 7, showing highest values around $1000 \mathrm{~cm}^{-3}$ for the months February through June. As a proxy for "the average aerosol over ZOTTO" we added to Fig. 6 the median size distribution for total particle number concentrations ranging $5 \%$ around their median.

\subsection{Back trajectory cluster analysis}

\subsubsection{Motivation}

Back trajectory analysis is a powerful tool to analyze atmospheric observations at a receptor point with respect to synoptic-scale transport processes. Since the late 1980s back trajectory cluster analysis has been applied to statistically analyze atmospheric flow patterns in oceanic (Harris and Kahl, 1990; Dorling and Davies, 1995), polar (Harris, 1992; Harris and Kahl, 1994), and continental (Owega et al., 2006) environments. The method has also proved successful in explaining trace gas observations (Cape et al., 2000) as well as near-surface aerosol concentrations (Oriol et al., 2004; Abdalmogith et al., 2008; Borge et al., 2007) including new particle formation events (Charron et al., 2001; Dal Maso et al., 2007). A key advantage of trajectory analysis over a manual synoptic analysis is the automated data treatment.

Previous works confirmed that the mixed layer height is instrumental in explaining near-surface aerosol concentrations in continental regions (Schäfer et al., 2006; Engler et al., 2007; Birmili et al., 2010). In summer, there is a significant diurnal cycle in surface temperature over the large landmass of Siberia, which leads to convection and a well-mixed planetary boundary layer with heights up to $2 \mathrm{~km}$ (Koutsenogii, 1997; Paris et al., 2009). In the absence of aerosol layers advected from distant sources, the concentrations of particles and anthropogenic trace gases will decrease in the afternoon along with the increase in mixing volume. In the presence of an inversion, aerosols emitted from near the surface can be trapped in a rather small volume. In practice, the vertical gradient of the pseudo-potential temperature $\theta_{\mathrm{v}}$, can be used to decide whether an air parcel has the ability to move and disperse vertically. In a cluster analysis, information on vertical stability can be incorporated in the shape of profiles of $\theta_{\mathrm{v}}$ (Engler et al., 2007; Birmili et al., 2010).

\subsubsection{Cluster method}

As a basis of the back trajectory clustering, 3D-backward trajectories were calculated for 2006-2009 using a PC-version 
of HYSPLIT, a trajectory model provided by the NOAA Air Resources Laboratory (Draxler and Hess, 2004). Back trajectories were calculated from the Global Data Assimilation System (GDAS) analysis set, which provides meteorological fields every $3 \mathrm{~h}$, a spatial horizontal resolution of $1^{\circ}$, and a vertical resolution corresponding to the standard pressure levels $(1000,925,850 \mathrm{hPa}$, etc.). Backward trajectories reaching $144 \mathrm{~h}$ back in time were computed for ZOTTO at the starting levels of 300, 1000 and $2000 \mathrm{~m}$ above the ground. Although the trajectories were computed for four times a day, only the 19:00 LT trajectory was analyzed further for consistency with the radio sounding ascents as outlined below. Due to computational problems at the $300 \mathrm{~m}$ trajectory starting level (trajectories hitting the ground), we used back trajectories starting at the $1000 \mathrm{~m}$ level only.

For our present study, we employed radio soundings from the meteorological station Bor $\left(61.6^{\circ} \mathrm{N}, 90.01^{\circ} \mathrm{E}\right.$, $58 \mathrm{~m}$ a.s.l.), about $100 \mathrm{~km}$ north of ZOTTO, whose measurements we assume to be representative of ZOTTO as well. Radio soundings at Bor are available daily at 07:00 and 19:00 LT. Due to the gradual development of vertical mixing through the day, measurements in the afternoon will be more representative for the entire boundary layer, and also for a wider horizontal area. For this reason, our trajectory cluster analysis focuses on aerosol measurements recorded in the afternoon, using solely the 19:00 LT radio sounding for the cluster analysis.

To provide DMPS data corresponding to the 19:00 LT radio sounding and back trajectory, particle number size distributions were averaged for the period between 14:0020:00 LT. For vertical air exchange, not the absolute temperature $\theta_{\mathrm{v}}$ is important but its vertical gradient. To make the vertical profiles comparable throughout all seasons, all profiles were normalized to $0{ }^{\circ} \mathrm{C}$ at a fixed height above ground. To avoid interference with very surface-related phenomena (such as local overheating), this critical height was set to $300 \mathrm{~m}$ above ground level.

The trajectory-clustering algorithm was a modification of the algorithm version used before for particle size distribution analysis (Engler et al., 2007; Birmili et al., 2010). It is principally based on the approach in Dorling et al. (1992). A fixed number of $k$ trajectory clusters is defined prior to analysis. The algorithm then aims at minimizing the distances between each object (3-D-trajectory plus $\theta_{\mathrm{v}}$ profile) to its cluster mean while maximizing the distances between all cluster means. In other words, trajectories are to be clustered in bundles as narrow as possible, with the mean trajectories in all bundles being as different as possible. As a measure for the distance $D$ between two objects, the following expression was used:

$D=\Sigma_{i}\left[l_{i} \cdot\left(\left(w_{\beta} \cdot \Delta \beta_{i}\right)^{2}+\left(w_{z} \cdot \Delta z_{i}\right)^{2}+\left(w_{\theta} \cdot \Delta \theta_{i}\right)^{2}\right)\right]$.

Here, $\Delta \beta$ is the distance between two trajectory points in degrees in spherical coordinates, $\Delta z$ distance between trajectories in the vertical dimension (height $z$ ), and $\Delta \theta$ the difference between two corresponding points in the vertical profiles of $\theta_{\mathrm{v}}$. All squared distances are summed over the entire length of the trajectory (index $i$ ), weighted with a distance factor $l_{i}$. (In analogy for the $\theta_{\mathrm{v}}$ profiles, all $i$ values corresponding to levels between $300 \mathrm{~m}$ to $3300 \mathrm{~m}$ above the surface were summed.) The distance factor $l_{i}$ was set to 1 at the start of the trajectory, and 0 at the end of each trajectory, linearly interpolating in between. (In analogy for the $\theta_{\mathrm{v}}$ profiles, the factor was one near the surface, and zero far aloft.). The distance factor ensures that distances between trajectories far from their terminal point at ZOTTO are not overemphasized. To make horizontal and vertical trajectory distances as well as distances in $\theta_{\mathrm{v}}$ comparable both in magnitude and units, these were multiplied by the appropriate weights $w_{\beta}$ (in $1 /^{\circ}$ ), $w_{z}\left(\right.$ in $1 \mathrm{~m}^{-1}$ ), and $w_{\theta}\left(\right.$ in $1 \mathrm{~K}^{-1}$ ).

In a first step, the cluster algorithm assigns all trajectories to one of the $k$ pre-defined clusters based on the minimum distance $D$ between the trajectories (and also radio sounding data). Specifically, the pre-defined clusters involved straight trajectories radiating from the ZOTTO site in different directions, thereby sharing equal segments of the $360^{\circ}$ horizon. When all data points were allocated to their appropriate seed trajectory by the principle of the minimum distance $D$, new cluster mean values were calculated from all data points (trajectory points, $\theta_{\mathrm{v}}$ profiles) within each cluster. Then, a new iteration was started, re-allocating all data points to the new cluster means using again minimizing $D$. This procedure was repeated until the allocation of data points to the $k$ clusters converged and no more re-allocation occurred.

It is an intrinsic property of the $k$-means clustering method that different initializations of the $k$ seed trajectories, such as involving slightly different wind directions, usually yield different clustering results, i.e. allocations of trajectories. It was also expected that the use of different weighing factors $w_{\beta}$, $w_{z}$ and $w_{\theta}$ would yield different clustering results. Therefore the cluster algorithm was run many times, using a range of cluster numbers $k$, and different angles of the $k$ seed trajectories. Also, a range of weights $w_{\beta}, w_{z}$ and $w_{\theta}$ was used to check the sensitivity of the clustering results with respect to variations in these weights. In total, 3000 cluster analyses were performed, most of which yielded different trajectory cluster compositions.

With respect to the weights $w_{\beta}, w_{z}$ and $w_{\theta}$, we checked how efficiently the particle size distributions were separated by each cluster analysis run. We computed a spread parameter representing the standard deviation within the set of mean particle size distributions resulting from each analysis, and weighted according to the number of trajectories in each cluster. If this spread parameter was high, a particular run is apparently well able to explain the particle size distributions as a function of the meteorological situation. It the spread parameter was low, the particular run was rather inefficient in splitting up the entire set of particle number size distributions. The analysis of the spread parameter yielded $w_{\beta}=1, w_{z}=10^{-9}$, and $w_{\theta}=2.2$ as the optimum values to 


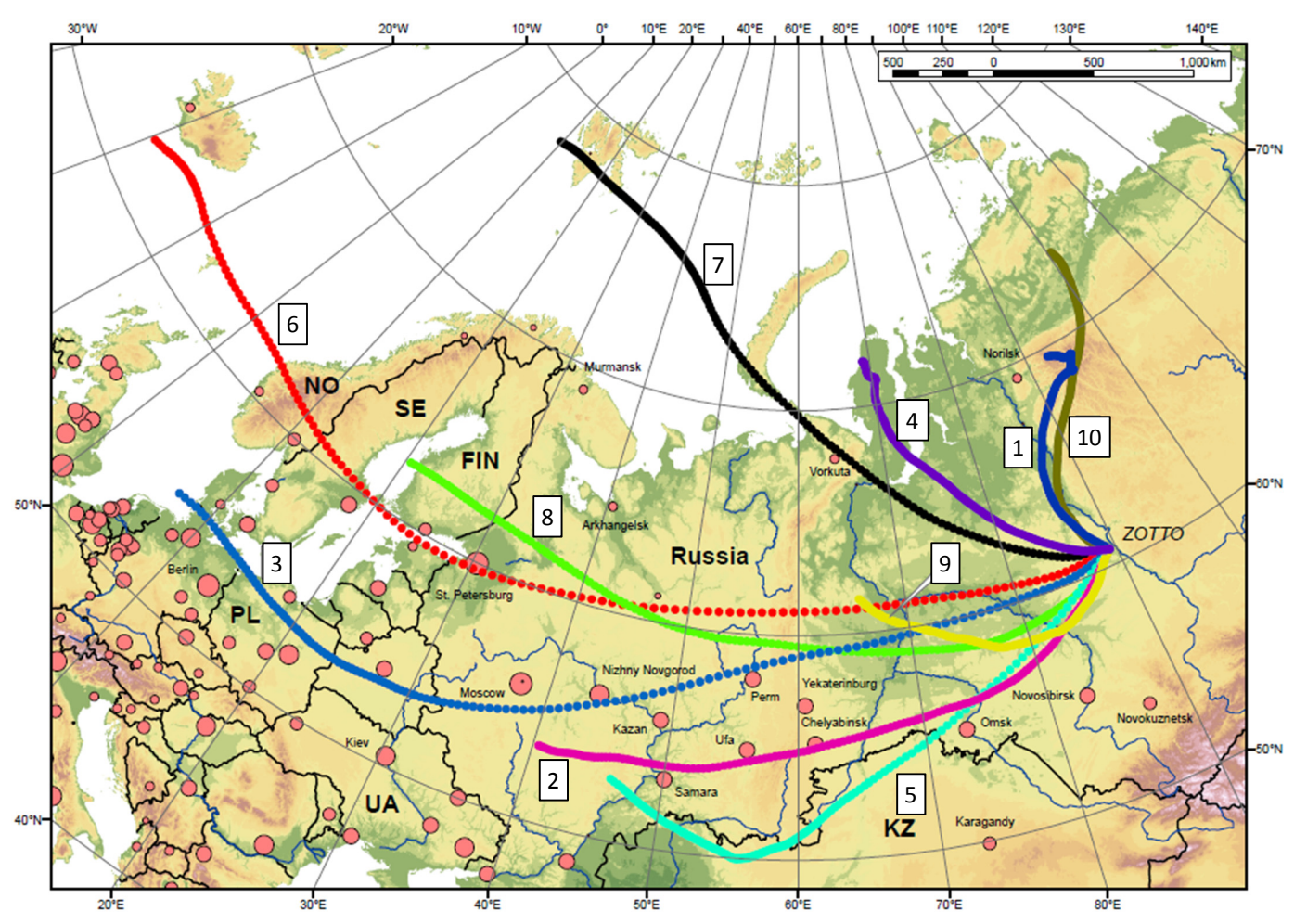

Fig. 8. Mean back trajectories arriving at ZOTTO as obtained from $k$-means cluster analysis. The travel time of all trajectories is $144 \mathrm{~h}$. The cluster numbering ranks the seasonality of the observations, ranging from cluster 1 (predominantly winter periods, season index -0.8 ) over cluster 6 (no preference, season index -0.1 ) to cluster 10 (predominantly summer periods, season index +0.6 ). Circles indicate urban agglomerations with the diameter of the symbol being proportional to the population size.

efficiently explain the variability in observed particle number size distributions. It became evident that the geographical origin of trajectories, $(\beta)$ and the vertical $\theta_{\mathrm{v}}$ profile mattered most, whereas effects in the computed vertical trajectory motion, $z$, remained largely irrelevant for the explanations of the surface-based aerosol measurements.

With respect to the cluster number, $k$, we finally made a compromise between fine resolution of spatial trajectory coverage (high $k$ ), and easily understandable display (low $k$ ). Each cluster should be understandable in terms of a synoptic situation and, preferably, also represent observations during a particular season. This yielded the number $k=10$, which is presented in the following.

\subsubsection{Cluster results}

The mean trajectories of the ten clusters obtained are displayed on a map with equidistant projection in Fig. 8. One can see that the ten mean trajectories successfully divide the overall data set according to different source regions and air mass speed. Trajectories tend to arrive at ZOTTO mainly from westerly and northerly directions as a result of the general west wind drift in mid-latitudes. One mean trajectory (cluster 6) travels the way from the Atlantic to ZOTTO during $144 \mathrm{~h}$, whereas others originate from Central Asia $(2,5)$ and others, again, from latitudes around $70^{\circ} \mathrm{N}$ and higher (1, $4,7,10)$.

Table 2 provides a summary of the ten clusters in terms of observed particle and meteorological parameters. For each cluster, a season index was calculated, scoring days in midwinter ( 15 January) as -1 , and days in mid-summer ( $15 \mathrm{July}$ ) as +1 , with sinusoidal interpolation in between. As a general rule, we numbered the clusters according to the predominant seasonal occurrence of the observations. According to the season index, the clusters $1-5$ correspond mainly to winter periods, the clusters 7-10 overwhelmingly to summer periods (see Table 2). Winter conditions prevailed especially in cluster 1 , with an average temperature of $-31^{\circ} \mathrm{C}$ and an air pressure of $1034 \mathrm{hPa}$, indicating the wintry Siberian highpressure area.

The seasonality of the boundary layer evolution is reflected in the mean profiles of the pseudo potential temperature, $\theta_{\mathrm{v}}$ (see Fig. 9). The profiles for the clusters 7-10 indicate a neutrally stable atmosphere in the lowest kilometer of the troposphere, as is the case in summer. A significant inversion, however, could be identified for clusters $1-4$, with increasing relevance.

The highest frequency of occurrence, by far, was attributed to cluster 10 (northeastern Siberia/summer) with $20 \%$ of the time (cf. Table 2). Altogether, the 
Table 2. Summary of the ten trajectory clusters including climatological frequency, characteristic season, mean meteorological parameters (air pressure, relative humidity, and temperature), mean particle concentrations at the $300 \mathrm{~m}$ level for several diameter intervals, and mean CO mixing ratios. The meteorological parameters are averages of the 19:00 LT observations at the Russian meteorological service station at Vorogovo, $30 \mathrm{~km}$ north of ZOTTO.

\begin{tabular}{|c|c|c|c|c|c|c|c|c|c|c|c|c|c|c|}
\hline \multirow{2}{*}{$\begin{array}{c}\text { Cluster } \\
\text { No. }\end{array}$} & \multirow{2}{*}{$\begin{array}{l}\text { Source } \\
\text { region }\end{array}$} & \multirow{2}{*}{$\begin{array}{c}\text { Frequ- } \\
\text { ency }\end{array}$} & \multirow{2}{*}{$\begin{array}{c}\text { Season } \\
\text { season index }\end{array}$} & \multirow{2}{*}{$\begin{array}{l}\text { Vertical } \\
\text { stability }\end{array}$} & \multirow{2}{*}{$\begin{array}{c}p \\
\text { in } \mathrm{hPa}\end{array}$} & \multirow{2}{*}{$\begin{array}{l}\mathrm{RH} \\
\text { in \% }\end{array}$} & \multirow{2}{*}{$\begin{array}{c}T \\
\text { in }{ }^{\circ} \mathrm{C}\end{array}$} & \multicolumn{6}{|c|}{ Particle number and mass concentrations } & \multirow{2}{*}{$\begin{array}{c}\mathrm{CO} \\
\text { in ppb }\end{array}$} \\
\hline & & & & & & & & $N_{a}$ & $N_{b}$ & $N_{c}$ & $N_{d}$ & $N_{\text {tot }}$ & $M$ & \\
\hline 1 & Northeastern Siberia & $5 \%$ & Winter $(-0.8)$ & very stable & 1034 & 74 & -31 & 27 & 110 & 190 & 100 & 430 & 3.2 & 148 \\
\hline 2 & Southern latitudes & $6 \%$ & Winter $(-0.8)$ & very stable & 1025 & 81 & -15 & 13 & 130 & 480 & 190 & 810 & 6.0 & 157 \\
\hline 3 & Central Europe & $4 \%$ & Winter $(-0.5)$ & stable & 1022 & 84 & -7 & 12 & 140 & 470 & 140 & 770 & 4.0 & 176 \\
\hline 4 & Arctic & $7 \%$ & Winter $(-0.4)$ & stable & 1016 & 81 & -13 & 27 & 90 & 240 & 100 & 450 & 2.7 & 145 \\
\hline 5 & Southern latitudes & $9 \%$ & Winter $(-0.3)$ & stable & 1013 & 82 & -1 & 25 & 210 & 720 & 260 & 1220 & 6.6 & 189 \\
\hline 6 & Northern Europe & $7 \%$ & $(-0.1)$ & stable & 1016 & 75 & +4 & 13 & 150 & 430 & 140 & 730 & 3.4 & 152 \\
\hline 7 & Arctic & $15 \%$ & Summer $(+0.3)$ & neutr. stable & 1013 & 65 & +4 & 22 & 100 & 230 & 80 & 440 & 1.9 & 139 \\
\hline 8 & Northern Russia & $12 \%$ & Summer $(+0.3)$ & neutr. stable & 1011 & 68 & +9 & 16 & 110 & 420 & 160 & 710 & 3.8 & 147 \\
\hline 9 & Central Siberia & $14 \%$ & Summer $(+0.4)$ & neutr. stable & 1008 & 74 & +10 & 14 & 100 & 430 & 190 & 730 & 4.5 & 147 \\
\hline 10 & Northeastern Siberia & $20 \%$ & Summer $(+0.6)$ & neutr. stable & 1011 & 61 & +11 & 13 & 70 & 360 & 160 & 600 & 4.0 & 127 \\
\hline
\end{tabular}

Season index: $-1=$ mid-winter (January 15), $+1=$ mid-summer (July 15); $N_{a}$ : Number concentration in the diameter range $15-30 \mathrm{~nm}^{-3} \mathrm{~cm}^{-3} ; N_{b}$ : Number concentration in the diameter range $30-60 \mathrm{~nm}$ in cm $\mathrm{cm}^{-3} ; N_{c}$ : Number concentration in the diameter range $60-200 \mathrm{~nm} \mathrm{in} \mathrm{cm}^{-3} ; N_{d}$ : Number concentration in the diameter range $200-800 \mathrm{~nm}$ in $\mathrm{cm}^{-3}$;

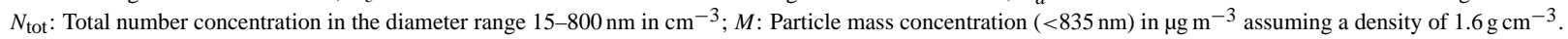

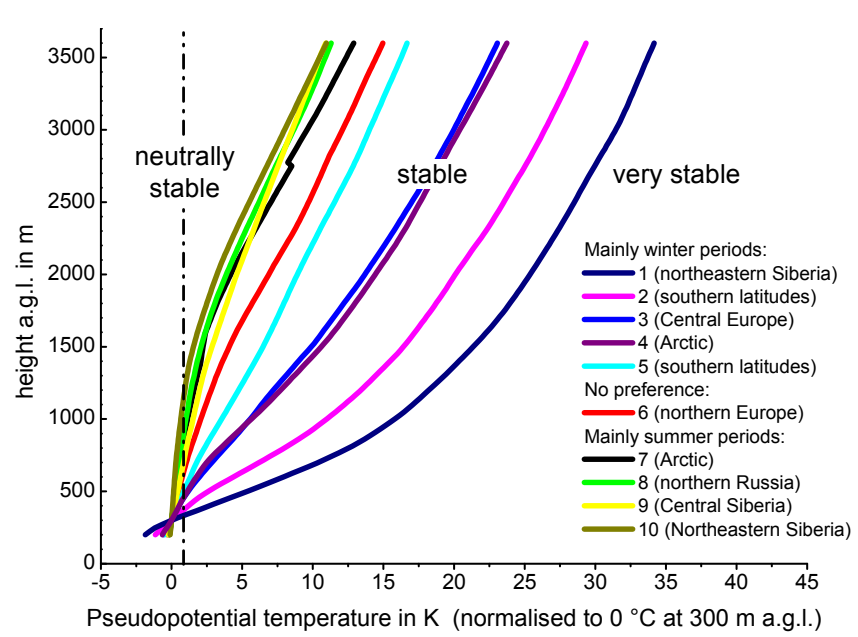

Fig. 9. Mean profiles of pseudo-potential temperature $\left(\theta_{\mathrm{V}}\right)$ for the ten trajectory clusters as a function of height. The profiles were part of the clustered variables in the $k$-means cluster analysis, and originated from the 19:00 LT radiosounding at Bor. The profiles allow a clear distinction between more and less stable stratification.

clusters 7 (Arctic/summer), 8 (northeastern Russia/summer), and 9 (Central Siberia/summer) account for more than $40 \%$ of all observation days. The clusters 1 (northeastern Siberia/winter), and 3 (Central Europe/winter) occurred more rarely, each contributing no more than $5 \%$ to the observation time. It is a particular observation that each cluster representing predominantly winter conditions represents a smaller fraction of the observation data compared to the "summer" clusters. Our impression is that the cluster algorithm facilitates such a partitioning because in the colder part of the year, the vertical stability (as illustrated in Fig. 9) tends to be more variable.
Figure 10 shows the average size distribution for each of the ten clusters. In both graphs, three different levels of particle concentration can be seen: Low concentrations $\left(d N / d \log D_{p}\right.$ ca. $\left.400 \mathrm{~cm}^{-3}\right)$ for clusters 1 (northeastern Siberia/winter), 4 (Arctic/winter) and 7 (Arctic/summer), mid-level concentrations $\left(d N / d \log D_{p}\right.$ ca. $\left.800-1000 \mathrm{~cm}^{-3}\right)$ for the clusters 2 (southern latitudes/winter), 3 (Central Europe/winter), 6 (northern Europe), 8 (northern Russia/summer), 9 (Central Siberia/summer), and high concentrations $\left(d N / d \log D_{p}\right.$ up to $1500 \mathrm{~cm}^{-3}$ ) for cluster 5 (southern latitudes/winter). Most number size distributions exhibit a unimodal overall shape with a number concentration maximum around $100 \mathrm{~nm}$. For the lower concentration clusters, a bimodal shape with a more obvious Hoppel minimum (Hoppel et al., 1990) between the Aitken and accumulation modes tens to emerge. Such distributions are indicative of remote background conditions where nucleation, growth by condensation and cloud processing are the dominant processes shaping the number size distribution.

The results for calculated total particle mass show a similar grouping: The clusters 2 (southern latitudes/winter) and 5 (southern latitudes/winter) show the highest average particle mass concentrations ( 6.0 and $6.6 \mu \mathrm{g} \mathrm{m}^{-3}$, respectively). It is worth mentioning that cluster 5 also shows the highest CO mixing ratio (189 ppb; see Table 2), and the highest particulate absorption coefficient $\left(1.6 \mathrm{Mm}^{-1}\right.$; not shown). The other clusters subsequently follow the order down to cluster 7 (Arctic/summer), which shows the lowest particle mass concentration $\left(1.9 \mu \mathrm{g} \mathrm{m}^{-3}\right)$.

A general finding is that the differences in particle number and mass concentrations between the clusters are rather modest. The total number concentration differs by a factor of 2.8 at maximum between the clusters, the particle mass concentration by a factor of 3.4 at maximum. One can see 

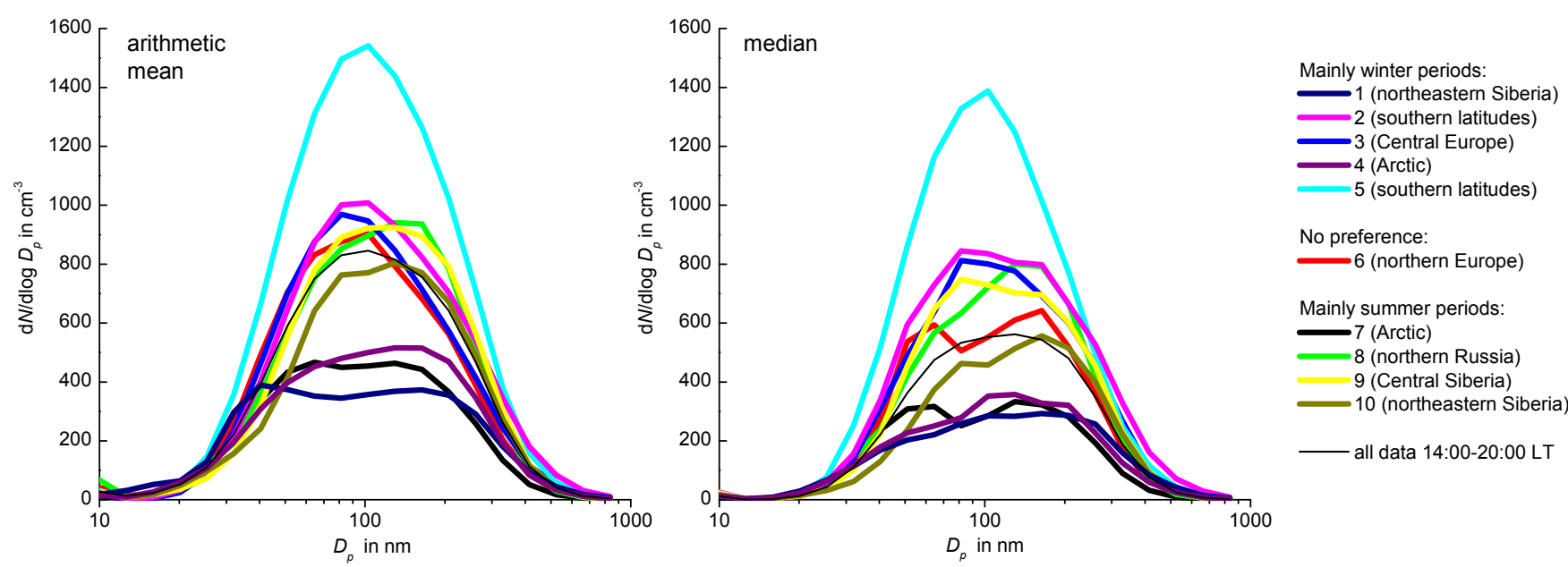

Fig. 10. Mean and median particle number size distributions for the ten trajectory clusters depicted in Fig. 8. Only data between 14:00 and 20:00 LT entered into the calculations, which correspond to the 19:00 LT radio sounding at Bor.

that the slower an air mass moves, and the more it originates at southerly latitudes, the higher will be the particle mass and number concentration as well as the $\mathrm{CO}$ mixing ratio. Anthropogenic emissions from the centers of population and industry are therefore suspected to be responsible for the elevated concentrations particularly in the clusters 2 and 5 .

Biomass burning events are more difficult to assess from the cluster analysis; in particular, we see no seasonal order in the size distributions of the trajectory clusters. The cluster orientation also misses out as a helpful indicator because the fires can hypothetically occur in any forested region of Siberia.

It is worth to note that new particle formation (defined as the production of particles at diameter $<30 \mathrm{~nm}$ ) occurred rather sporadically and did not show up in the average or median particle number size distributions in Fig. 10. This is in contrast, for example to average particle number size distributions in Scandinavia (Dal Maso et al., 2007; Kristensson et al., 2008) and Central Europe (Birmili et al., 2001; Engler et al., 2007), where new particle formation is a statistically more frequent phenomenon.

After all, the cluster analysis for ZOTTO confirms modest, but explainable variations in the particle number size distribution as a function of the synoptic scale meteorology. There appear to be three broad number concentration regimes: low particle concentrations around $400-500 \mathrm{~cm}^{-3}$ in Arctic air masses (except cluster 10 with a high summer index +0.6 ), medium concentrations around $600-800 \mathrm{~cm}^{-3}$ in zonally advected air masses from westerly directions, as well as the highest concentrations around $1200 \mathrm{~cm}^{-3}$ in slowly moving air from the southernmost latitudes. These results underline that the concentrations determined at ZOTTO are representative for a large spatial area of the Siberian ecosystem. This aspect makes the data set particularly useful for the validation of global aerosol transport models.

\subsection{Discussion}

Here, the implications of the results for the contributions of specific aerosol sources over Siberia are discussed. As a starting point, we presume that the ZOTTO aerosol measurements at the $300 \mathrm{~m}$ level are likely to be influenced by the following types of aerosol sources: (1) biomass burning, i.e. natural as well as man-made forest fires, (2) secondary formation, generating fresh particles as well as additional particle mass by gas-to-particle conversion, (3) significant anthropogenic point sources, such as industrial plants, (4) diffuse anthropogenic sources, such as domestic heating by private households, motor and ship traffic. In addition, aerosol from outside Siberia, both natural and anthropogenic can be advected into Siberia.

In the case of $\mathrm{CO}$, the impact of biomass burning on the observations at ZOTTO was clearly detectable during the warm seasons 2007 and 2008 (Vasileva et al., 2011). Our aerosol data revealed a significant annual peak in the month of July (Fig. 2). A visual screening of the particle number size distributions for individual events suggested that on 19/07/2007, apparently, ZOTTO was strongly influenced by forest fires within a range of a few tens of kilometers. This event could be recognized by a strongly variable signal of accumulation mode particles, and MODIS satellite images showed several smoke plumes in the region. However, if forest fires occur farther upwind, we would expect the air mass to become more homogeneous so that in general, it would be difficult to identify such events from particle size distributions alone.

Further evidence, however, was provided by the ratio $\sigma_{\mathrm{ap}} / V$, which serves as a proxy for the mass-specific light absorbance of the particle material. This ratio had an absolute minimum in July as well (Fig. 3). Kozlov et al. (2008) suggested the mass fraction of black carbon in sub- $\mu \mathrm{m}$ particles 
as an indicator of smoke from forest fires. The results shown in Fig. 3 are therefore in line with the maximum in particle number and volume concentration in July, when there is a maximum likelihood of forest fires. Although we conclude that forest fires are the likely cause of the July concentration maximum, it is difficult to judge their quantitative contribution even in this month, left alone in other months. A reason is that biomass burning has a similar seasonal cycle as secondary particle formation that enhances particle number (Kulmala et al., 2004) as well as mass (Tunved et al., 2006).

The formation of new atmospheric particle number (at $D_{p}<30 \mathrm{~nm}$ ) over Scandinavian boreal forest environments has its greatest occurrence in spring (Kulmala et al., 2004; Dal Maso et al., 2005). Similar evidence is available for various locations in Siberia (Dal Maso et al., 2008; Paris et al., 2009). Figure 2 showed elevated particle number concentrations (relative to particle volume) in the months FebruaryApril and June. At least for the months of March and later, it seems plausible that secondary particle formation influenced the observed particle mean concentrations at ZOTTO. (Before March, the environment at ZOTTO is usually completely frozen, snow-covered, with a rather short period of sunlight.)

A visual screening of the time evolution of the particle number size distributions at ZOTTO on individual days suggested the occurrence of between 10 and 20 clear particle formation and growth events per warm season, depending on the exact numerical criterion used. Fresh particle formation seems to occur not often enough to show up in any of the trajectory cluster mean size distributions (cf. Fig. 10). As a remarkable feature, however, numerous days showed the occurrence of nucleation mode diameter considerably bigger than $30 \mathrm{~nm}$, which persisted over many hours and sometimes several days, hence suggesting particle formation not near the site but further upwind. Although we refrain from a detailed analysis at this stage, the frequency of fresh particle formation events appears in any case to be substantially lower than at continental sites in Finland (Kulmala et al., 2004; Dal Maso et al., 2005) or Germany (Hamed et al., 2010), at maximum similar to that observed in Siberia directly by Dal Maso et al. (2008). In view of our limited experimental observations it remains speculative whether it could be a lack of certain gaseous precursors or particular meteorological conditions that make new particle formation events less visible at ZOTTO.

Apart from the atmospheric particle number budget, secondary formation over boreal forests is, in any case, acknowledged to have a significant impact on particulate mass (Tunved et al., 2006). The minimum particulate volume $V$ at ZOTTO was observed in October (Fig. 2). During the warm period (March-September), considerably higher values of $V$ were observed. While this observation could hint to secondary mass production, such as from biogenic precursors, the corresponding contributions are hard to distinguish from the possible background from biomass burning contributions.
Anthropogenic sources are likely to be associated with some of the strongest variation in the data set, notably the annual cycle of particle volume $V$ (cf. Fig. 2), the ratio $\sigma_{\mathrm{ap}} / V$ (cf. Fig. 3), and also the variation of the number size distribution as a function of season and air masses (cf. Fig. 10). It is plausible that the winter maxima in $V$ and $\sigma_{\text {ap }} / V$ (the measure for mass-specific absorbance) are related to fossil fuel combustion. The most significant single dependency adds to this impression: trajectories from latitudes far south of $60^{\circ} \mathrm{N}$ are associated with the highest concentrations of particle number, volume, and also $\mathrm{CO}$ (cf. clusters 2 and 5 in Fig. 8 and Table 2). Figure 8 illustrates that the Siberian centers of population and industry concentrate on a belt around $55^{\circ} \mathrm{N}$, predominantly located south-west of ZOTTO. As can be gleaned from Table 2 and Fig. 10, the aspect of geographic origin is of at least equal importance as the aspect of seasonality, since cluster 5 - associated the by far highest observed particle concentrations, shows a relatively modest seasonality towards the winter period only (season index -0.3 ).

A closer look at several individual case studies confirmed the large-scale nature of the anthropogenic effect. Polluted air masses often arrived when the back trajectories switched to south-westerly directions, and such situations often remained stable for a few days. The temporal continuity of the size distributions in many such cases suggested that the polluted air mass had achieved a high spatial homogeneity during the transport from the population and industrial centers to the remote ZOTTO site. This also weakens the likelihood that the mean size distribution ZOTTO is systematically influenced by the few local anthropogenic sources within a few $10 \mathrm{~km}$.

Lastly, we need to recognize the limitations of our source discussion: Although we found clear indications for specific groups of particle sources causing seasonal and geographical effects in the aerosol data, we are currently unable to quantify their absolute contributions to particle number and mass. A main reason is the lack of source-specific aerosol information, such as chemical composition. Our analysis of the more local processes is hampered by the lack of continuous local micrometeorological measurements, such as threedimensional wind on the tower for the early period 20062008. Such data, which is in process of being collected at ZOTTO at the time of writing, could clarify the possible roles of aerosol sources in the surroundings ZOTTO and their interaction with atmospheric mixing. We are aware that a more detailed classification and analysis of the time series in conjunction with satellite products might provide additional hints especially to the magnitude of the biomass burning aerosol sources. 


\section{Conclusions}

This paper covers measurements of the number-size distribution of aerosol particles taken from September 2006 to January 2010 at 50 and $300 \mathrm{~m}$ on the ZOTTO tower, Siberia at $60.8^{\circ} \mathrm{N} ; 89.35^{\circ} \mathrm{E}$. Additionally, particulate absorption at $570 \mathrm{~nm}$ wavelength and carbon monoxide (CO) as tracer gas were measured during much of the total time period. A statistical evaluation of the combined aerosol data set allowed drawing conclusions on three issues concerning the aerosol over the large Siberian forest area: representative integral particle properties and size distributions, the seasonal variation of the aerosol, and its possible sources.

Average number, surface and volume concentrations (and estimated mass concentrations) tend to be lower than those reported for boreal forest sites at similar latitude in Northern Europe (Tunved et al., 2005; Dal Maso et al., 2007). Comparisons of total particle number with previous experiments in Siberia (e.g., Dal Maso et al., 2008; Paris et al., 2009) yielded similar values but appear difficult in view of the differences in the instrumentation used.

For all integral parameters and all seasons the concentrations are higher at $50 \mathrm{~m}$ than at $300 \mathrm{~m}$, with their ratio being highest in number and lowest in volume concentrations. This suggests an impact of near-ground sources; we were, however, not able to further specify the type of these sources. The nearest large anthropogenic source is Krasnoyarsk, some $550 \mathrm{~km}$ to the south. When fitted with lognormal functions, the probability distribution function of modal diameters shows three main maxima in the Aitken and accumulation size range and a possible secondary maximum in the nucleation size range below $25 \mathrm{~nm}$.

The seasonal distributions of the different particle parameters differ substantially. Median soot-related particulate absorption has a clear single maximum in high winter (February) and minimum values in mid-summer. This distribution is typical for northern hemispheric combustion related aerosol parameters as seen in the Arctic haze (Heintzenberg, 1989). The 90th percentile, however, indicates a possible secondary maximum in July/August. The strongly combustion derived $\mathrm{CO}$ shows a single winter maximum and a late summer minimum, albeit with a considerably smaller seasonal swing than the particle data due to its longer atmospheric lifetime. Total volume and even more so total number show a more complex seasonal variation with maxima in winter, spring, and summer. Interestingly, the ratio of particulate absorption to volume has a more clearly expressed July minimum than absorption itself, indicating the possibility of non-combustion related particle sources over the Siberian summer forest.

Our cluster analysis of back trajectories complemented by local stability information yielded ten clusters with basically three levels of particle concentration: Low concentrations around $400-500 \mathrm{~cm}^{-3}$ in Arctic air masses, medium concentrations around $600-800 \mathrm{~cm}^{-3}$ in zonally advected air masses from westerly directions, and concentrations around $1200 \mathrm{~cm}^{-3}$ in slowly moving air from the southernmost latitudes. Most number size distributions peaked around $100 \mathrm{~nm}$. The highest number concentrations were associated with slowly moving air masses from south-western and southern, more populated areas. In Arctic air, a bimodal size distribution shape emerged with more evident Aitken and accumulation modes.

The multi-annual back trajectory statistics provided here as well as the independent analysis by Vasileva et al. (2011) suggested that the aerosol sampled at ZOTTO is representative for about half of the area of Russian Siberia. This representativeness makes the data set predestinated for the validation of global aerosol transport models. According to the current plans, the particle number size distribution and particulate absorption measurements will continue during the next years, and likely be complemented by chemical particle analysis by Russian partner institutions.

Acknowledgement. The Max Planck Society in collaboration with the V. N. Sukachev Institute of Forest established the ZOTTO facility after many years of preparatory fieldwork, planning and massive investments. We thank E.-D. Schulze and M. Heimann (MPI Biogeochemistry), A. A. Onuchin, and S. Verchovetz, (V. N. Sukachev Institute of Forest) for their contributions to the establishment and management of ZOTTO, and Y. Kisilyakhov, A. Tsukanov (V. N. Sukachev Institute of Forest), M. Welling and N. Jürgens (MPI Chemistry), as well as S. Leinert and T. Müller (IfT) for technical support. The ZOTTO project is funded by the Max Plank Society through the International Science and Technology Center (ISTC) partner project \#2757p within the framework of the proposal 'Observing and Understanding Biogeochemical Responses to Rapid Climate Changes in Eurasia', and by the German Research Council (DFG). We thank S. Schmidt and K. Kübler (MPI Jena) for their continuous logistic assistance during the experiment. We acknowledge U. Riebel (Technical University of Cottbus, Chair for Particle Technology) for generously sharing his technology of the corona discharge based aerosol neutralizer. We thank A. Wiedensohler (IfT Leipzig) for the fruitful discussions about environmental aerosol charging.

Edited by: V.-M. Kerminen

\section{References}

Abdalmogith, S. S. and Harrison, R. M.: The use of trajectory cluster analysis to examine the long-range transport of secondary inorganic aerosol in the UK, Atmos. Environ., 39, 6686-6695, 2005.

Achard, F., Mollicone, D., Stibig, H. J., Aksenov, D., Laestadius, L., Li, Z. Y., Popatov, P. and Yaroshenko, A.: Areas of rapid forestcover change in boreal Eurasia, Forest Ecol. Manage., 237, 322334, 2006.

Anderson, T. L. and Ogren, J. A.: Determining aerosol radiative properties using the TSI 3563 integrating nephelometer, Aerosol Sci. Tech., 29, 57-69, 1998.

Andreae, M. O.: Correlation between cloud condensation nuclei concentration and aerosol optical thickness in remote 
and polluted regions, Atmos. Chem. Phys., 9, 543-556, doi:10.5194/acp-9-543-2009, 2009.

Birmili, W., Wiedensohler, A., Heintzenberg, J., and Lehmann, K.: Atmospheric particle number size distribution in Central Europe: Statistical relations to air masses and meteorology. J. Geophys. Res., 106, D23, doi:10.1029/2000JD000220, 3200532018, 2001.

Birmili, W., Stopfkuchen, K., Hermann, M., Wiedensohler, A., and Heintzenberg, J.: Particle penetration through a $300 \mathrm{~m}$ inlet pipe for sampling atmospheric aerosols from a tall meteorological tower, Aerosol Sci. Technol., 41, 811-817, 2007.

Birmili, W., Heinke, K., Pitz, M., Matschullat, J., Wiedensohler, A., Cyrys, J., Wichmann, H.-E., and Peters, A.: Particle number size distributions in urban air before and after volatilisation, Atmos. Chem. Phys., 10, 4643-4660, doi:10.5194/acp-10-4643-2010, 2010.

Bond, T. C., Anderson, T. L., and Campbell, D.: Calibration and intercomparison of filter-based measurements of visible light absorption by aerosols, Aerosol Sci. Tech., 30, 582-600, 1999.

Borge, R., Lumbreras, J., Vardoulakis, S., Kassomenos, P., and Rodríguez, E.: Analysis of long-range transport influences on urban $\mathrm{PM}_{10}$ using two-stage atmospheric trajectory clusters, Atmos. Environ., 41, 4434-4450, 2007.

Brockmann, J. E.: Sampling and transport of aerosols. In: Aerosol Measurement - Principles, Techniques, and Applications, edited by: Baron, P. A. and Willeke, K., John Wiley \& Sons, New York, NY, USA, 143-196, 2001.

Cahoon, D. R. J., Stocks, B. J., Levine, J. S., Cofer, W. R. I., and Pierson, J. M.: Satellite analysis of the severe 1987 forest fires in northern China and southeastern Siberia, J. Geophys. Res., 99, 18627-18638, 1994

Cape, J. N., Methven, J., and Hudson, L. E.: The use of trajectory cluster analysis to interpret trace gas measurements at Mace Head, Ireland, Atmos. Environ., 34, 3651-3663, 2000.

Cappa, C. D., Lack, D. A., Burkholder, J. B., and Ravishankara, A. R.: Bias in filter-based aerosol light absorption measurements due to organic aerosol loading: Evidence from laboratory measurements, Aerosol Sci. Tech., 42, 1022-1032, 2008.

Charron, A., Birmili, W., and Harrison, R. M.: Factors influencing new particle formation at the rural site, Harwell, UK, J. Geophys. Res., 112, D14210, doi:10.11029/12007JD008425, 2007.

Dal Maso, M., Kulmala, M., Riipinen, I., Wagner, R., Hussein, T., Aalto, P. P., and Lehtinen, K. E. J.: Formation and growth of fresh atmospheric aerosols: eight years of aerosol size distribution data from SMEAR II, Hyytiälä, Finland, Bor. Environ. Res., 10, $323-$ 336, 2005

Dal Maso, M., Sogacheva, L., Aalto, P. P., Riipinen, I., Komppula, M., Tunved, P., Korhonen, L., Suur-Uski, V., Hirsikko, A., Kurtén, T., Kerminen, V.-M., Lihavainen, H., Viisanen, Y., Hansson, H.-C., and Kulmala, M.: Aerosol size distribution measurements at four Nordic field stations: identification, analysis and trajectory analysis of new particle formation bursts, Tellus, 59B, 350-361, 2007.

Dal Maso, M., Sogacheva, L., Anisimov, M. P., Arshinov, M., Baklanov, A., Belan, B., Khodzher, T. V., Obolkin, V. A., Staroverova, A., Vlasov, A., Zagaynov, V. A., Lushnikov, A., Lyubovtseva, Y. S., Riipinen, I., Kerminen, V. M. and Kulmala, M.: Aerosol particle formation events at two Siberian stations inside the boreal forest, Boreal Environ. Res., 13, 81-92, 2008.
Damoah, R., Spichtinger, N., Forster, C., James, P., Mattis, I., Wandinger, U., Beirle, S., Wagner, T., and Stohl, A.: Around the world in 17 days - hemispheric-scale transport of forest fire smoke from Russia in May 2003, Atmos. Chem. Phys., 4, 13111321, doi:10.5194/acp-4-1311-2004, 2004.

Dorling, S. R., Davies, T. D., and Pierce, C. E.: Cluster analysis: a technique for estimating the synoptic meteorological controls on air and precipitation chemistry - method and applications, Atmos. Environ., 26A, 2575-2581, 1992.

Dorling, S. R. and Davies, T. D.: Extending cluster analysis - synoptic meteorology links to characterise chemical climates at six northwest European monitoring stations, Atmos. Environ., 29, 145-167, 1995.

Draxler, R. R. and Hess, G. D.: Description of the HYSPLIT4 modeling system, NOAA Technical Memorandum, ERL, ARL224, available online at: www.arl.noaa.gov/documents/ reports/arl-224.pdf, 2004.

Engler, C., Rose, D., Wehner, B., Wiedensohler, A., Brüggemann, E., Gnauk, T., Spindler, G., Tuch, T., and Birmili, W.: Size distributions of non-volatile particle residuals $\left(\mathrm{D}_{\mathrm{p}}<800 \mathrm{~nm}\right)$ at a rural site in Germany and relation to air mass origin, Atmos. Chem. Phys., 7, 5785-5802, doi:10.5194/acp-75785-2007, 2007.

Gagné, S., Laakso, L., Petäjä, T., Kerminen, V.-M. and Kulmala, M.: Analysis of one year of Ion-DMPS data from the SMEAR II station, Finland, Tellus B, 60, 318-329, 2008.

Guyon, P., Frank, G. P., Welling, M., Chand, D., Artaxo, P., Rizzo, L., Nishioka, G., Kolle, O., Fritsch, H., Silva Dias, M. A. F, Gatti, L. V., Cordova, A. M., and Andreae, M. O.: Airborne measurements of trace gas and aerosol particle emissions from biomass burning in Amazonia, Atmos. Chem. Phys., 5, 29893002, doi:10.5194/acp-5-2989-2005, 2005.

Hamed, A., Birmili, W., Joutsensaari, J., Mikkonen, S., Asmi, A., Wehner, B., Spindler, G., Jaatinen, A., Wiedensohler, A., Korhonen, H., Lehtinen, K. E. J., and Laaksonen, A.: Changes in the production rate of secondary aerosol particles in Central Europe in view of decreasing $\mathrm{SO}_{2}$ emissions between 1996 and 2006, Atmos. Chem. Phys., 10, 1071-1091, doi:10.5194/acp-10-10712010, 2010.

Harris, J. M. and Kahl, J. D.: A descriptive atmospheric transport climatology for the Mauna Loa Observatory, using clustered trajectories, J. Geophys. Res., 95D, 13651-13667, 1990.

Harris, J. M.: An analysis of 5-day midtropospheric flow patterns for the South Pole: 1985-1989, Tellus B, 44, 409-421, 1992.

Harris, J. M. and Kahl, J. D. W.: Analysis of 10-day isentropic flow patterns for Barrow, Alaska: 1985-1992, J. Geophys. Res., 99D, 25845-25855, 1994.

Haywood, J. and Boucher, O.: Estimates of the direct and indirect radiative forcing due to tropospheric aerosols: A review, Rev. Geophys, 38, 513-543, 2000.

Heintzenberg, J.: Arctic haze: air pollution in polar regions, AMBIO, 18, 50-55, 1989.

Heintzenberg, J.: Properties of the log-normal particle size distribution, Aerosol Sci. Technol., 21, 46-48, 1994.

Heintzenberg, J., Birmili, W., Theiss, D., and Kisilyakhov, Y.: The atmospheric aerosol over Siberia, as seen from the $300 \mathrm{~m}$ ZOTTO tower, Tellus, 60B, 276-285, 2008.

Heintzenberg, J. and Birmili, W.: Aerosols over the Siberian forest: the ZOTTO project, J. Cryogen. Soc. Japan, 68, 5-8, 2010. 
Hoppel, W. A., Fitzgerald, J. W., Frick, G. M., Larson, R. E. and Mack, E. J.: Aerosol size distributions and optical properties found in the marine boundary layer over the Atlantic Ocean, J. Geophys. Res, 95, 3659-3686, 1990.

IGBP: Climate Change - only one Symptom of a Stressed Planet Earth. International Geosphere-Biosphere Programme, Royal Swedish Academy of Sciences, Stockholm, 2. February 2007, available online at: http://www.igbp.net, 2007.

Koutsenogii, P. K. and Jaenicke, R.: Number concentration and size distribution of atmospheric aerosol in Siberia, J. Aerosol Sci., 25, 377-383, 1994.

Koutsenogii, P.: Aerosol measurements in Siberia, Atmos. Res., 44, 167-173, 1997.

Kozlov, V. S., Panchenko, M. V., and Yausheva, E. P.: Mass fraction of black carbon in submicron aerosol as an indicator of influence of smoke from remote forest fires in Siberia, Atmos. Environ., 42, 2611-2620, 2008.

Kozlova, E. A., Manning, A. C., Kisilyakhov, Y., Seifert, T. and Heimann, M.: Seasonal, synoptic, and diurnal-scale variability of biogeochemical trace gases and $\mathrm{O}_{2}$ from a 300-m tall tower in central Siberia, Global Biochem. Cy., 22, GB4020, doi:4010.1029/2008GB003209, 2008.

Kozlova, E. A. and Manning, A. C.: Methodology and calibration for continuous measurements of biogeochemical trace gas and $\mathrm{O}_{2}$ concentrations from a 300-m tall tower in central Siberia, Atmos. Meas. Tech., 2, 205-220, doi:10.5194/amt-2-205-2009, 2009.

Kristensson, A., Dal Maso, M., Swietlicki, E., Hussein, T., Zhou, J., Kerminen, V.-M., and Kulmala, M.: Characterization of new particle formation events at a background site in Southern Sweden: relation to air mass history, Tellus B, 60, 330-344, 2008.

Kulmala, M., Vehkamäkia, H., Petäjä, T., Dal Maso, M., Lauri, A., Kerminen, V.-M., Birmili, W., and McMurry, P. H.: Formation and growth rates of ultrafine atmospheric particles: a review of observations, J. Aerosol Sci., 35, 143-176, 2004.

Lack, D. A., Cappa, C. D., Covert, D. S., Baynard, T., Massoli, P., Sierau, B., Bates, T. S., Quinn, P. K., Lovejoy, E. R., and Ravishankara, A. R.: Bias in filter-based aerosol light absorption measurements due to organic aerosol loading: Evidence from ambient measurements, Aerosol Sci. Tech., 42, 1033-1041, 2008.

Lloyd, J., Langenfelds, R. L., Francey, R. J., Gloor, M., Tchebakova, N. M., Zolotoukhine, D., Brand, W. A., Werner, R. A., Jordan, A., Allison, C. A., Zrazhewske, V., Shibistova, O., and Schulze, E.-D.: A trace-gas climatology above Zotino, Central Siberia, Tellus, 54B, 749-767, 2002.

Müller, D., Mattis, I., Wandinger, U., Ansmann, A., Althausen, D. and Stohl, A.: Raman lidar observations of aged Siberian and Canadian forest fire smoke in the free troposphere over Germany in 2003: Microphysical particle characterization, J. Geophys. Res., 110, D17201, doi:17210.11029/12004JD005756, 2005.

Oriol, J., Pérez, C., Rocadenbosch, F., and Baldasano, J. M.: Cluster analysis of 4-day back trajectories arriving in the Barcelona area, Spain, from 1997 to 2002, J. Appl. Meteororol., 43, 887-901, 2004.

Owega, S., Khan, B.-U.-Z., Evans, G. J., Jervis, R. E., and Fila, M.: Identification of long-range aerosol transport patterns to Toronto via classification of back trajectories by cluster analysis and neural network techniques, Chemometr. Intell. Lab. Syst., 83, 26-33, 2006.
Paris, J.-D., Arshinov, M. Y., Ciais, P., Belan, B. D., and Nédélec, P.: Large-scale aircraft observations of ultra-fine and fine particle concentrations in the remote Siberian troposphere: New particle formation studies, Atmos. Environ., 43, 1302-1309, 2009.

Pryor, S. C., Barthelmie, R. J., Sørensen, L. L., Larsen, S. E., Sempreviva, A. M., Grönholm, T., Rannik, Ü., Kulmala, M., and Vesala, T.: Upward fluxes of particles over forests: when, where, why?, Tellus B, 60, 372-380, 2008.

Reid, J. S., Koppmann, R., Eck, T. F., and Eleuterio, D. P.: A review of biomass burning emissions part II: intensive physical properties of biomass burning particles, Atmos. Chem. Phys., 5, 799825, doi:10.5194/acp-5-799-2005, 2005.

Schäfer, K., Emeis, S., Hoffmann, H., and Jahn, C.: Influence of mixing layer height upon air pollution in urban and sub-urban areas, Meteor. Z., 15, 647-658, 2006.

Schulze, E.-D., Lloyd, J., Kelliher, F. M., Wirth, C., Rebmann, C., Luehker, B., Mund, M., Knohl, A., Milyukova, I. M., and Schulze, W.: Productivity of forests in the Eurosiberian boreal region and their potential to act as a carbon sink - a synthesis, Global Change Biol., 5, 703-722, 1999.

Soja, A. J., Cofer, W. R., Shugart, H. H., Sukhinin, A. I., Stackhouse, P. W., McRae, D. J., and Conard, S. G.: Estimating fire emissions and disparities in boreal Siberia (1998-2002), J. Geophys. Res.-Atmos., 109, D14S06, doi:10.1029/2004JD004570, $2004 a$.

Soja, A. J., Sukhinin, A. I., Cahoon, D. R., Shugart, H. H., and Stackhouse, P. W.: AVHRR-derived fire frequency, distribution and area burned in Siberia, Int. J. Remote Sens., 25, 1939-1960, 2004 b.

Spracklen, D. V., Bonn, B., and Carslaw, K. S.: Boreal forests, aerosols and the impacts on clouds and climate, Phil. Trans. R. Soc. A, 366, 4613-4626, doi:10.1098/rsta.2008.0201, 2008.

Stocks, B. J., Fosberg, M. A., Lynham, T. J., Mearns, L., Wotton, B. M., Yang, Q., Jin, J.-Z., Lawrence, K., Hartley, G. R., Mason, J. A., and McKenney, D. W.: Climate change and forest fire potential in Russian and Canadian boreal forests, Clim. Change, 38, 1-13, 1998.

Stommel, Y. G., and Riebel, U.: A new corona discharge-based aerosol charger for submicron particles with low initial charge, J. Aerosol Sci., 35, 1051-1069, 2004.

Tunved, P., Nilsson, E. D., Hansson, H.-C., Ström, J., Kulmala, M., Aalto, P., and Viisanen, Y.: Aerosol characteristics of air masses in northern Europe: Influences of location, transport, sinks, and sources, J. Geophys. Res., 110, D07201, doi:10.01029/02004JD005085, 2005.

Tunved, P., Hansson, H.-C., Kerminen, V.-M., Ström, J., Dal Maso, M., Lihavainen, H., Viisanen, Y., Aalto, P. P., Komppula, M. and Kulmala, M.: High Natural Aerosol Loading over Boreal Forests, Science, 312, 261-263, 2006.

Vartiainen, E., Kulmala, M., Ehn, M., Hirsikko, A., Junninen, H., Petäjä, T., Sogacheva, L., Kuokka, S., Hillamo, R., Skorokhod, A., Belikov, I., Elansky, N. and Kerminen, V.-M.: Ion and particle number concentrations and size distributions along the Trans-Siberian railroad, Bor. Environ. Res., 12, 375-396, 2007.

Vasileva, A. V., Moiseenko, K. B., Mayer, J.-C., Jürgens, N., Panov, A., Heimann, M. and Andreae, M. O.: Assessment of the regional atmospheric impact of wildfire emissions based on $\mathrm{CO}$ observations at the ZOTTO tall tower station in Central Siberia. J. 
Geophys. Res. 116, D07301, doi:07310.01029/02010JD014571, 2011.

Virkkula, A., Ahlquist, N. C., Covert, D. S., Arnott, W. P., Sheridan, P. J., Quinn, P. K., and Coffman, D. J.: Modification, calibration and a field test of an instrument for measuring light absorption by particles, Aerosol Sci. Tech., 39, 68-83, 2005.

Weingartner, E., Saathoff, H., Schnaiter, M., Streit, N., Bitnar, B., and Baltensperger, U.: Absorption of light by soot particles: determination of the absorption coefficient by means of aethalometers, J. Aerosol Sci., 34, 1445-1463, 2003.
Winderlich, J., Chen, H., Gerbig, C., Seifert, T., Kolle, O., Lavrič, J. V., Kaiser, C., Höfer, A., and Heimann, M.: Continuous low-maintenance $\mathrm{CO}_{2} / \mathrm{CH}_{4} / \mathrm{H}_{2} \mathrm{O}$ measurements at the Zotino Tall Tower Observatory (ZOTTO) in Central Siberia, Atmos. Meas. Tech., 3, 1113-1128, doi:10.5194/amt-3-1113-2010, 2010.

Winklmayr, W., Reischl, G. P., Lindner, A. O., and Berner, A.: A new electromobility spectrometer for the measurement of aerosol size distributions in the size range from 1 to $1000 \mathrm{~nm}$, J. Aerosol Sci., 22, 289-296, 1991. 